\title{
Valorization of Agri-Food Wastes as Sustainable Eco-Materials for Wastewater Treatment: Current State and New Perspectives
}

\author{
Ecaterina Matei ${ }^{1}$, Maria Râpă ${ }^{1}$, Andra Mihaela Predescu ${ }^{1, *}$, Anca Andreea Țurcanu ${ }^{2}$, Ruxandra Vidu ${ }^{1,3} \mathbb{C}^{\text {, }}$ \\ Cristian Predescu ${ }^{1, *}$, Constantin Bobirica ${ }^{4}$, Liliana Bobirica ${ }^{4}$ and Cristina Orbeci ${ }^{4}$
}

1 Faculty of Materials Sciences and Engineering, University POLITEHNICA of Bucharest, 060042 Bucharest, Romania; ecaterina.matei@upb.ro (E.M.); maria.rapa@upb.ro (M.R.); rvidu@ucdavis.edu (R.V.)

2 Center for Research and Eco-Metallurgical Expertise, Faculty of Materials Science and Engineering, University POLITEHNICA of Bucharest, 060042 Bucharest, Romania; anca.turcanu@upb.ro

3 Department of Electrical and Computer Engineering, University of California Davis, One Shields Avenue, Davis, CA 95616, USA

4 Faculty of Applied Chemistry and Materials Science, University POLITEHNICA of Bucharest, 060042 Bucharest, Romania; constantin.bobirica@upb.ro (C.B.); liliana.bobirica@upb.ro (L.B.); cristina.orbeci@upb.ro (C.O.)

* Correspondence: andra.predescu@upb.ro (A.M.P.); cristian.predescu@upb.ro (C.P.); Tel.: +40-214-029-592 (A.M.P. \& C.P.)

check for

updates

Citation: Matei, E.; Râpă, M.;

Predescu, A.M.; T,urcanu, A.A.; Vidu,

R.; Predescu, C.; Bobirica, C.; Bobirica,

L.; Orbeci, C. Valorization of

Agri-Food Wastes as Sustainable

Eco-Materials for Wastewater

Treatment: Current State and New

Perspectives. Materials 2021, 14, 4581.

https://doi.org/10.3390/ma14164581

Academic Editor: Farooq Sher

Received: 27 July 2021

Accepted: 11 August 2021

Published: 15 August 2021

Publisher's Note: MDPI stays neutral with regard to jurisdictional claims in published maps and institutional affiliations.

Copyright: (c) 2021 by the authors. Licensee MDPI, Basel, Switzerland. This article is an open access article distributed under the terms and conditions of the Creative Commons Attribution (CC BY) license (https:/ / creativecommons.org/licenses/by/ $4.0 /)$.

\begin{abstract}
The paper addresses environmental protection by valorizing an important agri-food waste category, namely fruit and vegetables with focusing on the main characteristics regarding consumption, waste quantities, and ways for valorizing these materials. Thus, vast research was undertaken in order to emphasize the main commodities and their potential application as adsorbents for organic and inorganic pollutants. The main methods or treatment techniques applied for the valorization of eco-materials as adsorbents were presented and the principal efficiency results were indicated. The advantages and disadvantages of using these eco-materials as adsorbents in wastewater treatment were revealed and future recommendations were established. According to the international statistics, the most purchased and consumed five commodities were studied regarding waste generations as potential conversion into eco-materials with an adsorbent role for water pollutants. Thus, the performances for adsorbents based on fruit wastes (such as citrus, banana, apples, grapes, mango) and vegetable wastes (such as potatoes, tomatoes, cabbage, carrots, cauliflower, and/or broccoli) were studied and highlighted in this research.
\end{abstract}

Keywords: agri-food wastes; eco-materials; wastewater treatment

\section{Introduction}

Nowadays, the ecosystem's health and life quality are strongly determined by the wastes quantities that are gradually increasing. At a global level, the agro-industry generates valuable materials as agri-food wastes with well-known potential. These possess natural bioactive compounds with utilization in the food, pharmaceutical, and cosmetics industry or composting, energy, and bioethanol production [1-5]. However, a large quantity of agri-food wastes linked with economic pressure on resource sustainability requires more attention concerning the agro-industrial waste use and recycling methodologies [6]. In the last 50 years, agricultural activities have become more intense and the use of fertilizers and pesticides have given rise to inequality between productivity and environmental factors, and soil requiring more organic matter. In these circumstances, agricultural wastes could be integrated by clean technologies or be returned as an organic substrate to the soil as valuable materials, with minimum risk to environmental factors and ecosystems. Moreover, these materials could be used as animal food, combustion raw materials, or disposed to landfills, but with high implications on environmental issues. Due to their 
microbial decomposition agri-food wastes could be associated with some potential risks for the environment and their treatment is compulsory [7].

As a rule, agri-food wastes have a complex structure and composition consisting of polysaccharides, proteins, carbohydrates, polyphenolic constituents, etc. [8,9]. These properties could offer the possibility of using them as renewable natural resources. In addition, agri-food wastes are inexpensive, easy to access, ecofriendly, and sustainable. Under these considerations, these types of wastes are evaluated as eco-materials. Applying different physical and chemical treatments and activation methods, the agri-food wastes could be converted into a carbonized biomass (charcoal) with well-developed microporosity and functional groups at the surface acting as sorbents [10-12] or ion exchangers [13-19]. The adsorption capacity of these low-cost adsorbents is comparable to the commercially activated carbon having roles in organic and inorganic pollutants removal from synthetic solutions and wastewaters [20]. Olivera et al. identified five categories of sorbents obtained from agri-food wastes: activated carbons, biosorbents, bone char, adsorbents with chitin, and chitosan content, and ion exchange resins [7]. Given their origins, agri-food wastes, and especially fruit and vegetable wastes, were tested for different applications such as bioactive compounds used for obtaining, discoloring of sugar and vegetable oils, and removal of copper ions from the beverage industry [7].

Agro-industrial wastes represent a feasible solution for environmental conservation and natural resources protection. Their composition offers a large spectrum of applications. Figure 1 illustrates the main reuse directions of agri-food wastes as valuable materials.
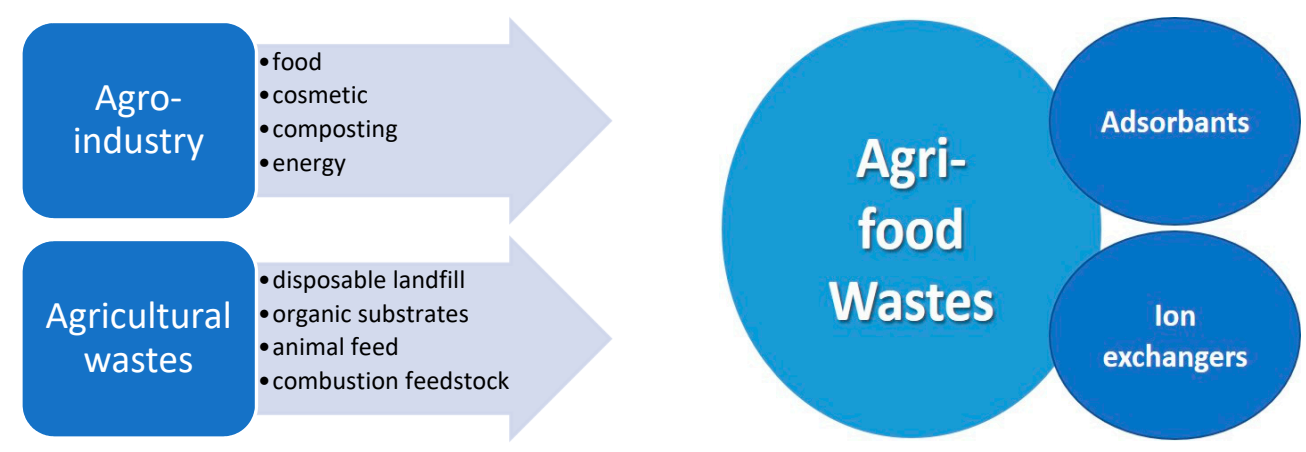

Figure 1. The main sources of agri-food wastes and their applications.

The agri-food industrial sector generates important quantities of agricultural wastes. In their studies, Garske et al. stated that food could be wasted at the household level, with a negative impact on natural resources and the environment [21]. A way to take advantage of these wastes as inexpensive and sustainable materials is to convert them into low-cost adsorbents. So far, there were many research papers published in recent years, with a focus on inorganic and organic pollutants removal, and some review papers [22-25] reveal significant information and lead to a comprehensive understanding of the potential use of these agri-food wastes as low-cost adsorbents.

A recently published article estimated that $180 \mathrm{~kg}$ of food per person and per year $(\mathrm{kg} / \mathrm{p} / \mathrm{y})$ are wasted annually in the EU, keeping in mind that the food wastes generated from the preparation to consumption stage and that the households are the highest contributor to food waste generation. The study points out that EU households have the highest participation in food waste production. The quantity of wastes resulted annually from fruits and vegetables is approximated at $35.3 \mathrm{~kg}$ per person per year, from which $14.2 \mathrm{~kg}$ could be avoidable [26]. According to these studies, the quantified food waste was $123 \mathrm{~kg} / \mathrm{p} / \mathrm{y}$, in the case of households and food services [27]. With respect to the fruit and vegetables (including potatoes) commodities, almost $63 \%$ results as food wastes. These commodities, representing about one-third of food and exposed inedible parts (such as peel, seeds, etc.) are short-lived and low-cost. The literature indicates differences between 
the quantity of avoidable and unavoidable wastes from country to country, based on consumers' behavior, possibly due to the cultural and economic components.

The utilization of different agricultural wastes as eco-materials with adsorption capacities for the water and wastewater treatment, dedicated to organic and inorganic pollutants removal, linked with the efficiencies, and regeneration performances data for analyzed fruit and vegetables wastes are summarized in this review paper. In addition, different functionalized or treated method wastes and mechanisms of pollutants removal are presented, where it was applicable as the current state of research. Based on this synthesis, the highest development, and future directions and needs, are discussed on the preparation of novel adsorbents as eco-materials using fruit and vegetable wastes. All information is focused on the top five commodities regarding both fruits (citrus, banana, apples, grapes, and mango) and vegetables (potatoes, tomatoes, cabbage, carrots, cauliflower, and/or broccoli) consumption according to the Food and Agriculture Organization of the United Nations (FAO) statistics, as mainly waste generation sources. Conclusions are based on the literature reviewed. The paper also establishes the future research perspectives in the field of adsorbents utilization when agricultural wastes are used for water treatment applications.

\section{Agri-Food Waste Quantification}

There are different definitions regarding agri-food wastes. Considering the definition of FAO, food waste is described as food that is not suitable for human consumption after expiring or becoming tainted. This definition is supported by the food degradation but could also be due to the oversupply on the market or consumer eating habits. The other definition given by The Food Use for Social Innovation by Optimizing Waste Prevention Strategies (FUSIONS) project, funded by the European Commission, refers to the food waste as part of "food and spoiled parts of food removed from the food supply chain" to be recovered or stored (composting, anaerobic digestion, co-generation, incineration, etc.) [28].

Furthermore, Kummu and colleagues found differences between food losses and food wastes, the first one referring to production, postharvest, and processing of products, and the second one being associated with distribution and consumption activities [29].

As the origin, agri-food wastes are generated from (a) agricultural, (b) forest, (c) municipal, and (d) industrial activities. All of these wastes are of the organic type and can include livestock slurry, manure, pruning, and maintenance activities of woodlands to degummed fruits and legumes, bagasse, sludge from wool, cellulose, etc.

As crops, sugarcane (21\% in 2018), maize (13\% in 2018), rice (9\% in 2018), and wheat ( $8 \%$ in 2018) are the most produced worldwide by quantity [30]. It has been estimated that rice, corn, and wheat represent together over $33 \%$ of all calories spent by the world population, while fruit and vegetables represent over $23 \%$. As wastes, these quantities are expected to grow and are susceptible to have harmful effects on the environment [31]. Raw materials obtained from rice straw, rice husk, corncob, and wheat straw might be converted into valuable products such as bioethanol [32,33], biomass-degrading enzymes [34], biogas [35], antioxidants [36], adsorbents [37], lactic acid [38], husk charcoal briquettes or husk charcoal for replacement of fossil fuel, and anticoagulants [39]. Moreover, some of these materials are also used for eco-friendly composites production, such as waste-wood [40].

Lignin and cellulose have as primary components $-\mathrm{OH}$ and $-\mathrm{COOH}$ functional groups that can substitute the $\mathrm{H}^{+}$with $\mathrm{As}(\mathrm{III}), \mathrm{Cd}(\mathrm{II}), \mathrm{Cr}(\mathrm{IV}), \mathrm{Hg}(\mathrm{II}), \mathrm{Pb}(\mathrm{II})$, and $\mathrm{Ni}(\mathrm{II})$ as metalloids and metal ions in order to generate complexes, as it was tested for grape and apple wastes, grounds from tea and coffee, nutshells, leaves, algae, rice, and sunflower plants [41]. In order to enhance the adsorption capacity and reinforce the functional groups potential of these agricultural waste-derived adsorbents, their structure can be modified by different physical and chemical pre-treatments, obtaining carbonaceous materials (biochar), with high surface area and pore volume [42,43].

The forest wastes, such as hardwoods (oak, maple, hickory, and birch) and softwoods (pine, spruce, fir, and juniper) represent two major types of wood waste that could be 
valorized as important products for obtaining active packaging for protection against oxidative damage of food [44]. In addition, different active components from wood wastes could be reintegrated in oil-based products, such as ethanol, lignin products, and vanillin [31]. Usually, wood wastes (at small sizes as chips or fibers) could be converted into new materials such as composites using "cascade" applications as efficient resources conservation and carbon storage actions [40].

The processing of food and vegetables is responsible for the generation of agri-food wastes. According to Tokusoglu [45], the production and conservation of fruits and vegetables produce almost $14.8 \%$ of food waste derivatives, being the third industry, after the beverage industry $(26 \%)$ and cheese, milk, and ice cream industry $(21.3 \%)$. With a lower percentage, the fabrication of starch and grain crops $(12.9 \%)$, oils and fats $(3.9 \%)$, the production and processing of meat products $(8 \%)$, and fish and fish commodities $(0.4 \%)$ are also contributors as agri-food waste generation.

Ben-Othman and colleagues stated that agricultural wastes (almost reaching up to $50 \%$ ) are responsible for negative environmental impacts [46]. The FAO report identified four hotspots in terms of food wastages (the term "wastage" comprises both food loss and waste) related to significant environmental issues. These hotspots refer mainly to the carbon footprint evaluated from wastage of cereals ( $34 \%$ of total), especially from the high quantities of rice wastage, wastage of meat ( $21 \%$ of total) with substantial impact on the environment concerning land occupation, fruit wastage (6\% of total) caused by food wastage volumes, and vegetable wastage ( $21 \%$ of total), mainly due to large wastage volumes [47]. According to other publications, the FAO estimated that the most amount of food that is wasted or lost refers to the fruit, vegetables, and seafood industry, and represents one-third of all the produced food [46,48]. Among agri-food wastes, fruit and vegetable commodities induce critical losses and wastes quantities, both in fresh and processing industries, turning into a serious threat regarding nutritional, economical, and environmental issues. It was evaluated that the losses and wastes generated by fruits and vegetables total $60 \%$ from all types of foods and processing operations covering about $25 \%$ to $30 \%$ of wastes from the whole commodity group [49].

Under these circumstances, wastage must be minimized in the agri-food sector. To achieve these goals, all these agri-food wastes have already been used as a source of fuel, livestock feeds, or organic fertilizers. Today, based on the main research and development topics, eco- and green technologies are one of the most reliable and efficient domains to sustain durability and resource conservation. Halada and Yamamoto describe the ecomaterials as materials that build up a higher level of environmental protection across their life cycle without reducing their performance [50]. An example is shown in Figure 2.

Wastes are mainly made of peels, seed, pomace, and skin and these could have potential benefits as bioactive substrates. Among these, carotenoids, polyphenols, dietary fibers, enzymes, vitamins, and oils are essential in the health and food applications, or textile industry. The wastes that can be converted into bioactive compounds lead to a sustainable environment.

Each year, significant quantities of fruits are produced globally: 126.29 million metric tons (MMT) of citrus in the first place, 116.78 MMT of bananas as the second commodity, 87.24 MMT of apples as the third commodity, 77.14 MMT of grapes in fourth place, followed by mangoes, mangosteens, and guavas (about 55.85 MMT), and pineapples (about 28.18 MMT) [51]. Regarding vegetable production, the most important quantity is represented by potatoes (3820.00 MMT) and tomatoes (180.77 MMT), followed by cabbages and other brassicas (70.15 MMT), carrots and turnips (44.76 MMT), cauliflower and broccoli (26.91 MMT), and peas (21.77 MMT) [52]. The production of fruits and vegetables is presented in Figure 3. 


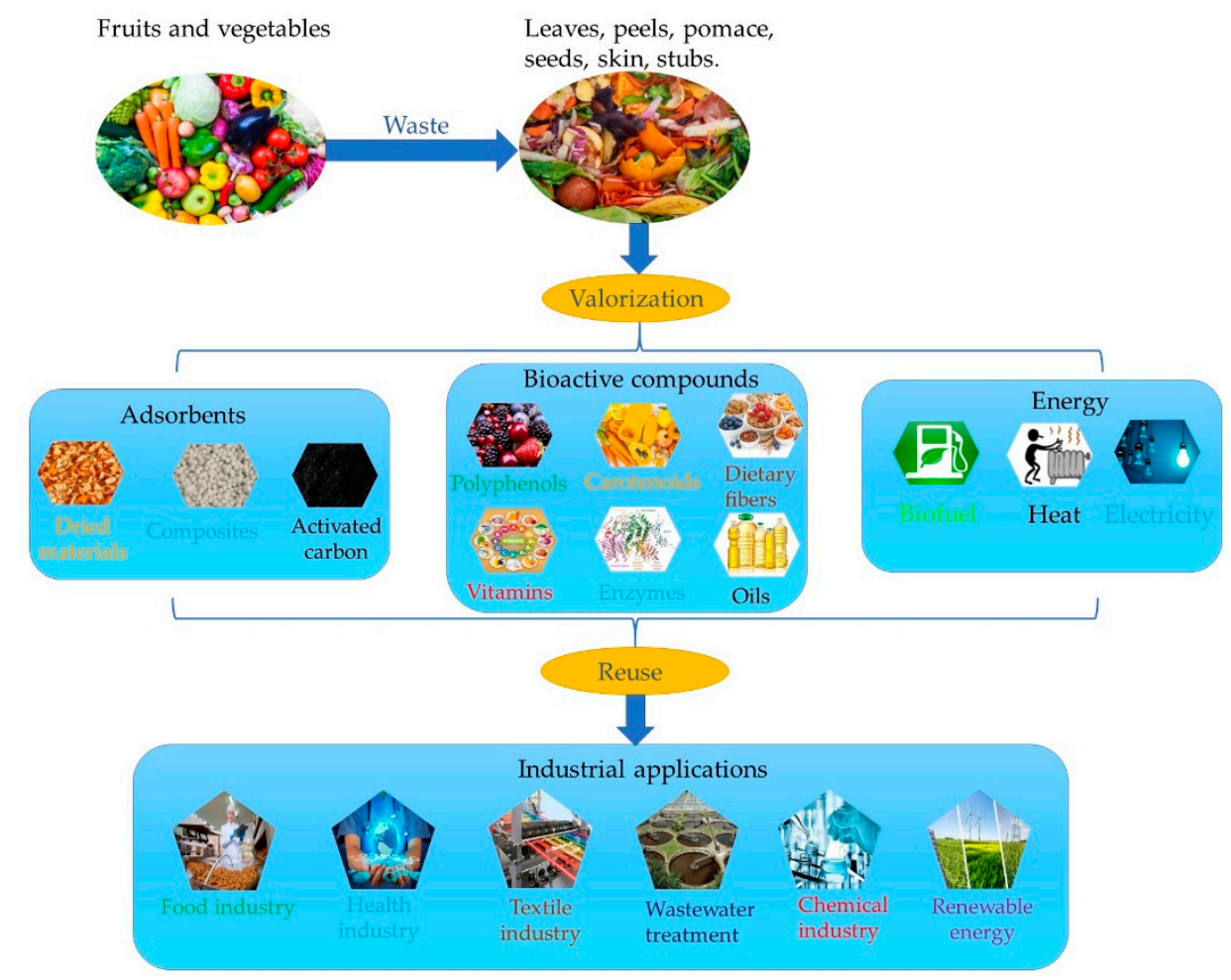

Figure 2. A way to minimize agri-food wastes by their conversion into valuable products.

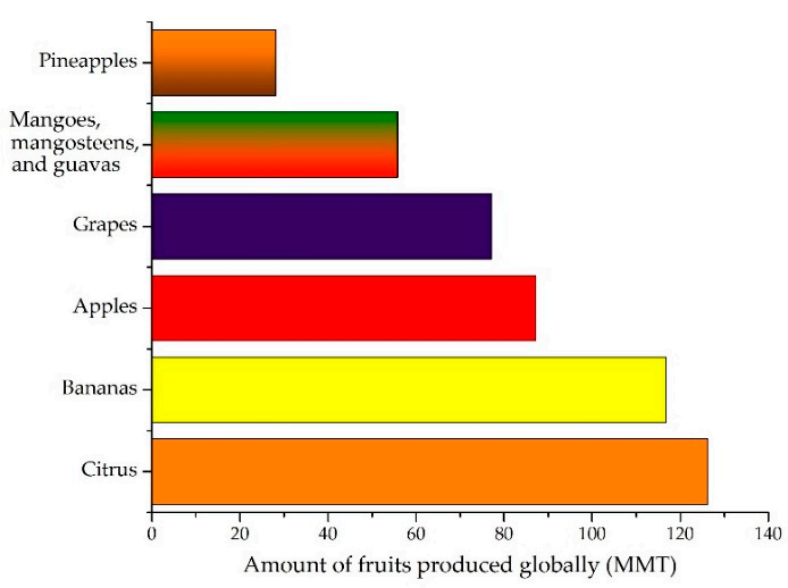

(a)

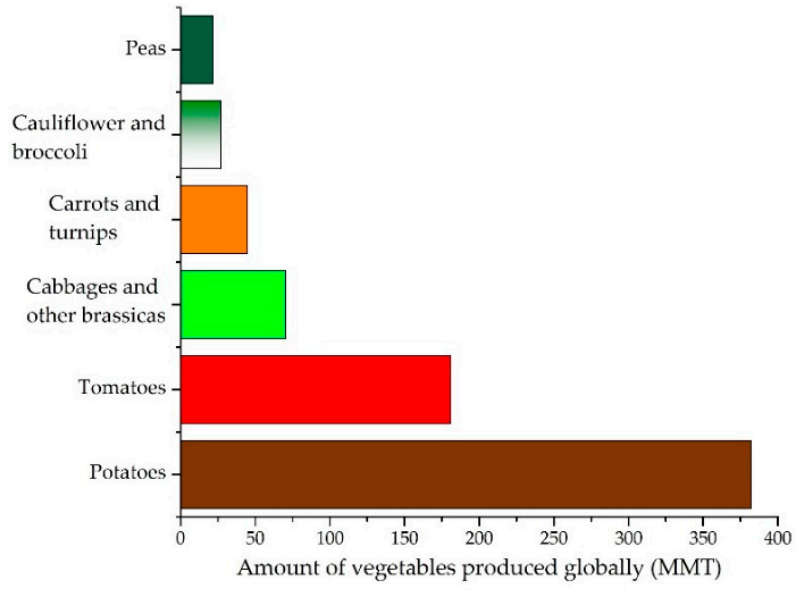

(b)

Figure 3. Globally produced fruits (a) and vegetables (b).

\section{Environmental Impact of Fruit and Vegetable Wastes}

Due to the large production growth, combined with the absence of appropriate methods and infrastructure for manipulation, the waste and losses of these food commodities increased alongside their residue quantities. The FAO has assumed that at least one-third of the world's food (estimated as 931 MMT in 2019) is lost and wasted annually (UNEP Food Waste Index Report 2021), while the horticultural commodities waste ranks first among all types of foods, reaching up to $60 \%$ [53]. These wastes result from the combined production and manipulation stages including the supply chain, classification, and ranking, marketing, storage, and processing.

Through his research, Sagar et al. highlighted that about 55 MMT of fruit and vegetable wastes are generated in developed areas from China, India, the Philippines, and the United States. These wastes result from processing, packaging, distribution, and consumption 
activities [49]. It was observed that an important quantity of fruit and vegetables are becoming wastes as a postharvest process before reaching the consumer and another high quantity is generated after consuming, especially in developing countries. A major threat appears concerning the decomposing of these fruit and vegetable wastes when harmful greenhouse gases are evacuated [49]. During industrial processing, fruit and vegetable wastes are produced in significant quantities; being necessary an adequate management and recycling stage is required due to their harmful environmental impact. These wastes have different characteristics morphologies and various unused and residual parts such as leaves, roots, peels, pulp, tubers, seeds, pomace, etc. [54,55]. Concerning the apple wastage, $89.09 \%$ resulted during the slicing and $10.91 \%$ consist of seed and pulp. Papaya wastage consists of about $8.5 \%$ as peel resulting from dicing, $6.5 \%$ as seeds, and $32 \%$ as useless pulp (due to the imperfection in cubes), and about $53 \%$ is represented as the final product. In the case of mandarins, the rate is about $16 \%$ peels and $84 \%$ of the final product. Pineapple generates about $15 \%$ of pulp, $15 \%$ of the top $14 \%$ of peels, $9 \%$ of the core, and $48 \%$ as the final product. The mango industry generates about $13.5 \%$ of seeds, a percentage of $18 \%$ represent the inoperable pulp, $11 \%$ as peels, and $58 \%$ as the final product $[56,57]$. In addition, fruit and vegetable juice preparation generates about 5.5 MMT of wastes (along with pomace). Each year, the wine and grape industry produces from 5 to 9 MMT of solid waste, and between $20 \%$ and $30 \%$ represent the processed materials [58]. Moreover, about $30 \%$ as a percentage of the leaves and stems result from canning and frozen industries, which generate about 6 MMT of solid waste each year [55].

The nature of fruit and vegetable wastes are different for each country, and additional aspects should be considered: exported transport, harvest size, processing steps, and especially energy and waters consumption as these place pressures on ecosystems. Besides these, circular economy approaches help to develop economically sustainable models and environmental protection. Del Borghi and coworkers stated in their research that the demands of the water-energy-food nexus sector are decisive on the quality of the ecosystem. These decisions are regulated within circular economy provisions especially with regard to food waste management and related to environmental degradation and climate change [59]. It is obvious that food wastes and by-products could be converted into high-added-value raw materials that contribute to environmental savings, energy, water, and greenhouse gas (GHGs) emissions abatement. Today, the total amount of GHGs emitted by a product throughout its life cycle is expressed as its carbon footprint $(\mathrm{CF})$ in kilograms of equivalent $\mathrm{CO}_{2}$. The $\mathrm{CF}$ calculus for food products differs from site to site being connected with the year of production, local conditions, and variability of natural processes. Thus, different food products have different carbon intensities, some examples are presented in Table 1.

Table 1. Carbon footprint during the production and generation of wastes of some fruits and vegetables.

\begin{tabular}{|c|c|c|c|}
\hline \multicolumn{2}{|c|}{ CF of Fruits and Vegetables } & \multicolumn{2}{|c|}{ CF of Generated Wastes } \\
\hline Commodity & $\mathrm{CF}$ as $\mathrm{CO}_{2}$ Equiv. & Waste Data & $\mathrm{CF}$ as $\mathrm{CO}_{2}$ Equiv./kg [60] \\
\hline Banana & $\begin{array}{c}100-200 \mathrm{~g} \mathrm{CO}_{2} \text { equivalents (eq) per } \\
\text { banana [61] }\end{array}$ & $\begin{array}{c}\text { 30-40\% peel (about } 34.72-46.29 \text { MMT, } \\
\text { 2018) [62] }\end{array}$ & 5.7 \\
\hline Citrus & $\begin{array}{c}0.07-0.64 \mathrm{~kg} \mathrm{CO} \text { eq } / \mathrm{kg} \text { produced with } \\
\text { a median value of } 0.29 \text { [63] }\end{array}$ & About $15-25,000 \mathrm{t}$ waste/year [1] & $\begin{array}{c}2.1 \text { as orange } \\
0.5 \text { as lemon } \\
0.2 \text { as grapefruit } \\
0.25 \text { other citrus }\end{array}$ \\
\hline Grapes & $0.846 \mathrm{~kg} \mathrm{CO} 2 \mathrm{eq} / \mathrm{kg}[64]$ & $\begin{array}{l}\text { 25\% by-product/waste (as pomace, } \\
\text { including skins, seeds from wine } \\
\text { production) }[65]\end{array}$ & 0.9 \\
\hline
\end{tabular}


Table 1. Cont.

\begin{tabular}{|c|c|c|c|}
\hline \multicolumn{2}{|c|}{ CF of Fruits and Vegetables } & \multicolumn{2}{|c|}{ CF of Generated Wastes } \\
\hline Commodity & $\mathrm{CF}$ as $\mathrm{CO}_{2}$ Equiv. & Waste Data & $\mathrm{CF}$ as $\mathrm{CO}_{2}$ Equiv./kg [60] \\
\hline Apples & $\begin{array}{c}2.4 \text { to } 5 \text { t of } \mathrm{CO}_{2} \text { eq/ha/year ( } \mathrm{New} \\
\text { Zealand) [66] }\end{array}$ & $\begin{array}{l}25 \% \text { apple pomace (where: about } 3 \% \\
\text { seeds, } 95 \% \text { skin and } 1 \% \text { stems) [67] }\end{array}$ & 1.2 \\
\hline Mango & From 0.06 to $0.18 \mathrm{~kg}$ of $\mathrm{CO}_{2} \mathrm{eq} / \mathrm{kg}$ [68] & $\begin{array}{c}25 \% \text { to } 40 \% \text { of the raw material is left as } \\
\text { a residue (from } 260.000 \text { t) [69] }\end{array}$ & 2.1 as exotic fruit \\
\hline Tomatoes & $\begin{array}{l}\text { Values varied between } 0.1-10.1 \mathrm{CO}_{2} \\
\text { eq } / \mathrm{kg} / \text { year [70] }\end{array}$ & $\begin{array}{l}3-7 \% \text { raw material lost as waste (where } \\
\text { about } 10 \% \text { seeds ) [71]. }\end{array}$ & 8.2 \\
\hline Potatoes & $\begin{array}{c}0.10-0.16 \mathrm{~kg} \mathrm{CO} \text { eq } / \mathrm{kg} \text { with } 95 \% \\
\text { certainty for an arbitrary year and } \\
\text { field [72] }\end{array}$ & $\begin{array}{l}5.8 \text { million per day are thrown away } \\
\text { (UK householders) [73] } \\
15-40 \% \text { peel of the initial potato mass } \\
\text { as major waste [74] }\end{array}$ & 0.3 \\
\hline Cabbage & $0.12 \mathrm{~kg} \mathrm{CO} 2 \mathrm{eq} / \mathrm{kg}[75]$ & $32.5 \%(13,406.25 \mathrm{t}$ average annual) [76] & 0.1 \\
\hline Carrots & N.D. & $\begin{array}{c}30 \% \text { waste resulted from processing } \\
\text { step (from 60,214 t/year in } \\
\text { Switzerland) [77] }\end{array}$ & 0.1 \\
\hline Cauliflower & $3.67 \mathrm{~kg} /$ unit ha/year [78] & $\begin{array}{c}37.1 \% \text { or } 27,825 \text { tons on-farm and } 24 \% \\
\text { between the farm and the final } \\
\text { consumer as average wastes } \\
\text { annually [76] }\end{array}$ & 0.3 \\
\hline
\end{tabular}

The Food and Agriculture Organization estimated that $8 \%$ of GHGs responsible for the planet's heating are provided from food waste and half of all fruit and vegetables produced are wasted (3.7 trillion are apples) [47]. In these conditions, a GHG emissions assessment using CF is a complex procedure of food waste impact calculus. The presented examples are not comprehensive, but the overall aspects are to be considered with local specificity. For example, agri-food products are produced differently, with different resources, in different locations, and specific lifecycles. These products are shipped in different conditions, resulting in direct (transportation, production, etc.) and indirect (land use) emissions [79]. Thus, high significant uncertainties appear in GHG budgets and CF assessments. There are many studies, procedures, and methodologies developed for measuring the impact of food products as commodities and especially of resulting wastes with the specific pressures on environments.

\section{Valorization of Agri-Food Wastes as Ecological Adsorbents}

From all of the parts of unused commodities that result as wastes, peels were spotted as an ecological burden, but their lignocellulosic content encourages research for the preparation of rich biomass eco-materials, as renewable, low cost, and sustainable adsorbents for water and wastewaters treatment applications. In addition, fruit and vegetable wastes as peels are included in the containers from households in a very high percentage. Peels and skins from fruit and vegetables are a natural source, with eco-friendly and economical potential to be used as adsorbents in order to remove different pollutants from different types of water and reduce pollution, remaining a renewable and sustainable resource [5].

Today, there are plenty of treatment technologies being applied for diminishing water pollution and control of environmental quality [80]. Despite the economic features, such as high operational and maintenance costs, and also the generation of toxic sludge, the adsorption process is considered a better and low-cost option for water and wastewaters treatment. This is supported by its accessibility, variety of removed pollutants, easiness in operation, and design [5]. Activated carbon is a well-known material used as a common adsorbent both for gaseous and liquid pollutants for which the only restriction appears in terms of costs. In the last decades, various types of low-cost adsorbents were de- 
veloped, characterized, and tested and the results were comprehensively studied and published [12,23,81-87].

A low-cost adsorbent means a material with high abundance in nature or resulted from the industry as waste with a large valorization capacity and minimum processing and the adsorption potential should be at least comparable with the one from the commercial activated carbon. However, even if the biomass from agri-food wastes could replace activated carbon as an eco-friendly material, after its treatment and activation, the research concerning their performances indicated insufficient removal potential for aquatic pollutants, thus, research is ongoing. The availability and abundance of agri-food wastes and their potential to replace natural resources exploitation with low costs are reasons for extending research and considering them as a viable option for water and waste-water treatment. Among these, "waste peels" from fruits and vegetables are attractive and promising eco-materials; most of the peels being wastes without any other application and with severe impact on the environment but with high potential to become a resource for water treatment technologies [5].

The main chemical components of fruit and vegetable wastes are lignin and cellulose that contain different functional groups from alcohols, aldehydes, ketones, carboxylic, phenolic, and ether classes [5]. Due to their polarity, these functional groups expose the capacity to link aquatic pollutants such as metals, dyes, organic compounds, usually by adsorption mechanism. Usually, the literature indicates the mass transfer process as the main step to remove pollutants by using agri-food wastes (as adsorbents), enhancing the accumulation capacity of adsorbent expressed as the pollutant quantity adsorbed, and residual pollutant concentration from solution $[5,80,88]$. An important aspect of adsorption efficiency is the mechanism of pollutant removal that depends on the physical and chemical characteristics of the adsorbent. In order to establish the proper mechanism, parameters as the potential rate-controlling step, kinetic models, and isotherm adsorption are studied $[89,90]$. The $-\mathrm{COOH}$ functional groups are responsible for complexation sites, whereas both $-\mathrm{OH}$ and $-\mathrm{COOH}$ groups are involved in cation exchange sites. A significant role in the adsorption process could have the ion exchange phenomena, especially when chemical modification of material takes place in order to increase the number of active binding sites and form new functional groups for pollutant removal $[5,83,88]$. Ionic exchange mechanism was reported in the case of the absorption process of water pollutants for lignin.

According to their chemical structure, fruit and vegetable wastes could be used only as dried materials or after advanced chemical and physical treatments [91-95]. The performances of wastes are based on different shapes and sizes obtained after treatment. Through physical treatment, the precursors are initially carbonized, then are subjected to an activation process with steam or $\mathrm{CO}_{2}$. Chemical treatment involves impregnating precursors with an activating agent, followed by a process of heating in an inert gas atmosphere [92,96-100]. Activating agents could dissolve the cellulose composition of the precursor and lead to the crosslinking process [100]. Chemical activation is preferred to physical activation. It requires low temperatures, produces high yields, a large area of specific surface area, involves only one step for the development of micropores, and mineral content decrease in comparison with physical activation [91,101-103]. One of the challenges of the chemical activation represents the washing step where corrosive agents could be used for the impurities removal [104].

\section{Types of Pollutants}

Water quality remains one of the most concerning problems of the world. Natural disasters, extreme weather events, water supply crises, even flooding, expose water resources to real challenges regarding consumption and quality. On the other side, today's materials have to be designed according to the next generation that includes active and nanostructured materials, with attractive and advanced properties that can convert waste materials into valuable designed materials with application in water and wastewater treatment. To- 
day, the classical treatment methods (from primary to tertiary treatments) expose the risk of producing secondary pollutants. A challenge is represented by the use of different materials with the same high efficiency and with a low concentration level of secondary pollutants generation. In this case, the use of the adsorbents from biomass represents a blueprint for the water and wastewaters-an efficient and cost-effectively treatment. The literature presents elaborated reviews with a focus on the main agricultural and non-agricultural products acting as adsorbents due to their possible mechanisms for pollutant removal. The main subjects approached by the literature are preparation methods, with the possibility of modifying waste properties for enhanced performance, mechanisms of the pollutant's removal, re-usability options, and cost-benefit ratio, as possible future developments.

According to Younas et al., there is a real challenge regarding the treatment methods of wastewaters in correlation with the pollutant sources [41]. The authors identified two main sources, natural and derived from anthropogenic activities, emphasizing the generation sources for those pollutants that seriously affect the environment and health. Thus, the agriculture sector and households generate wastewaters containing inorganic pollutants such as heavy metals and nutrients, along with hydrocarbons, endocrine disruptors, and other organic pollutants. In addition, bacteria, viruses, and protozoa from waters are frequently identified and monitored as microbial contaminants. Together with nutrients such as phosphorus and nitrogen, water could be affected by eutrophication, which is responsible for the growth of toxin-producing cyanobacteria.

Moreover, the effect of the presence in waters of non-biodegradable and other pollutants is their persistence in the environment for long periods of time. This leads to an accumulation in progressive levels in the biological food sequence. As a solution for these negative effects, various processes are used in order to achieve wastewater treatment before being discharged into the river body. Heavy metals and metalloids, such as $\mathrm{Cu}, \mathrm{Cd}, \mathrm{Zn}$, $\mathrm{Fe}, \mathrm{Pb}, \mathrm{HgSn}, \mathrm{As}, \mathrm{Al}, \mathrm{Ag}, \mathrm{Mn}, \mathrm{Cr}, \mathrm{Co}$, and Ni were identified in many water bodies. These elements expose higher mobility and solubility and are also persistent in the environment, leading to negative environmental and health effects. Besides these, organic pollutants (biocides, phenols, dyes, petroleum, oils, fats, proteins, starches, and medicines) affected the water quality with a significant environmental impact on ecosystem quality. Linked with these issues, many studies were carried out on the impact of heavy metals and organics on water quality, considering their harmful effects on human health. Thus, numerous advanced techniques were studied, such as adsorption on new adsorbents, membrane filtration, reverse osmosis, nanofiltration, electrodialysis, photocatalysis, phytoremediation, chemical and physical remediation, and microbial remediation processes, emphasizing the advantages and limitations in organic compounds and heavy metals removal [105-112]. Even if the efficiency of these techniques is proven by converting a large number of pollutants into harmless products, another important volume of secondary products results as wastes. In order to scale down these issues regarding waste generation, different organic and inorganic adsorbents were developed, with different adsorption capacities and efficiencies (activated carbon, clay minerals, zeolite, polymer materials, agricultural waste, etc.). The literature presents vast information about these types of materials. Focusing on agricultural wastes (as vegetables and fruits), the main parameters and efficiency data are summarized in Table 2. Due to their performances and environmental impact, even after their life-cycle, some of these materials could be associated as eco-materials, with added-value, ecofriendly, and sustainable properties. 
Table 2. Examples of uses of vegetable wastes as adsorbents for water pollutants.

\begin{tabular}{|c|c|c|c|c|}
\hline Vegetables & $\begin{array}{c}\text { Type of Waste/Treatment } \\
\text { Conditions }\end{array}$ & Eco-Materials Parameters & $\begin{array}{l}\text { Pollutants and Adsorption } \\
\text { Efficiency Data }\end{array}$ & References \\
\hline \multirow{6}{*}{ Potatoes } & $\begin{array}{l}\text { Untreated potato peel, dried at } 50^{\circ} \mathrm{C} \\
\text { for } 7 \text { days }\end{array}$ & N.A. & $\mathrm{Cu}(\mathrm{II}) 84.74 \mathrm{mg} / \mathrm{g}$ & {$[113,114]$} \\
\hline & Chemical activated $0.5 \mathrm{M} \mathrm{NaOH}$ & N.A. & $\begin{array}{c}\mathrm{Cd}(\mathrm{II}) 90 \mathrm{mg} / \mathrm{g} ; \mathrm{Cu} \mathrm{II}) \\
41.7 \mathrm{mg} / \mathrm{g} ; \mathrm{Ni}(\mathrm{II}) 16.7 \mathrm{mg} / \mathrm{g} ; \\
\mathrm{Zn} \text { (II) } 52.6 \mathrm{mg} / \mathrm{g} ; \mathrm{Mn}(\mathrm{II}) \\
47.6 \mathrm{mg} / \mathrm{g} ; \mathrm{Fe}(\mathrm{II}) 76.9 \mathrm{mg} / \mathrm{g}\end{array}$ & {$[114,115]$} \\
\hline & $\begin{array}{l}\text { Pyrolysis and treatment with } \mathrm{ZnCl}_{2} \\
\text { (chemical activation) of peels }\end{array}$ & $\begin{array}{c}\text { BET: } 1078 \mathrm{~m}^{2} / \mathrm{g} \\
\text { V pores: } 0.97 \mathrm{~cm}^{3} / \mathrm{g}\end{array}$ & $\begin{array}{l}\mathrm{Cu} \text { (II) } 62 \mathrm{mg} / \mathrm{g} \text { and } 74 \mathrm{mg} / \mathrm{g} \\
\text { for } 160 \mathrm{wt} . \% \mathrm{ZnCl}_{2}\end{array}$ & {$[114,116]$} \\
\hline & $\begin{array}{c}\text { Thermal treatment at } \\
400,600,800{ }^{\circ} \mathrm{C}(\mathrm{P} 400, \mathrm{P} 600), \\
\text { chemical activated with solution } \\
75 \%(w / w) \mathrm{H}_{3} \mathrm{PO}_{4}\end{array}$ & $\begin{array}{l}\text { BET P400: } 904.56 \mathrm{~cm}^{2} / \mathrm{g}, \\
\text { V pores: } 0.726 \mathrm{~cm}^{3} / \mathrm{g} \\
\text { BET P600: } 1041.43 \mathrm{~cm}^{2} / \mathrm{g}, \\
\text { V pores: } 2.960 \mathrm{~cm}^{3} / \mathrm{g}\end{array}$ & $\begin{array}{c}\text { Co (II): } 373 \mathrm{mg} / \mathrm{g} \text { for } \mathrm{P} 400 \text { and } \\
405 \mathrm{mg} / \mathrm{g} \text { for P600 }\end{array}$ & {$[114,117]$} \\
\hline & $\begin{array}{l}\text { Thermal activation at } 600^{\circ} \mathrm{C} \\
\text { (activated carbon peel }(\mathrm{ACP}) \text { ) }\end{array}$ & $\begin{array}{c}\text { BET } 498 \mathrm{~m}^{2} / \mathrm{g} \\
\text { V pores } 0.987 \mathrm{~cm}^{3} / \mathrm{g}\end{array}$ & $\mathrm{Pb}(\mathrm{II})$ & {$[114,118]$} \\
\hline & Potato peels as charcoal (PPC) & N.A. & $\begin{array}{c}\mathrm{Cu}(\mathrm{II}) 0.3877 \mathrm{mg} / \mathrm{g}(99.8 \%) \\
\text { \%Recovery: } 5 \text { repeated cycles } \\
\quad \text { (last cycle: } 99.5 \% \pm 0.35)\end{array}$ & {$[114,119]$} \\
\hline \multirow[t]{2}{*}{ Tomatoes } & Leaf powder & $\begin{array}{c}\text { BET } 5.0518 \mathrm{~m}^{2} / \mathrm{g} \\
\mathrm{V} \text { pores } 0.003 \mathrm{~cm}^{3} / \mathrm{g}\end{array}$ & NI (II) $58.82 \mathrm{mg} / \mathrm{g}$ & [120] \\
\hline & Chemical activation with $\mathrm{NaOH}$ & $\begin{array}{c}\text { BET: } 8.83 \mathrm{~m}^{2} / \mathrm{g} \\
\text { V pores } 0.0447 \mathrm{~cm}^{3} / \mathrm{g}\end{array}$ & $\begin{array}{c}\mathrm{Pb}(\mathrm{II}) 152 \mathrm{mg} / \mathrm{g}(97 \%) \\
\text { Desorbtion studies: } \mathrm{HCl} \text { : } \\
53.473 \%, \mathrm{Na}_{2} \text {-EDTA: } 94.247 \%\end{array}$ & [121] \\
\hline Cabbages & Powder, $102{ }^{\circ} \mathrm{C}, 24 \mathrm{~h}$ & BET: $1.0265 \mathrm{~m}^{2} / \mathrm{g}$ & $\begin{array}{c}\mathrm{Pb}(\mathrm{II}) 60.57 \mathrm{mg} / \mathrm{g}(98.85 \%) \\
\mathrm{Cd}(\mathrm{II}) 20.57 \mathrm{mg} / \mathrm{g}(54.32 \%) \\
\text { Recovery: } \mathrm{Pb}(\mathrm{II}) 86.67 \% \text { and } \\
\mathrm{Cd} \text { (II) } 82.34 \%\end{array}$ & [122] \\
\hline Carrots & & N.A. & $\begin{array}{c}\mathrm{Cr}(\mathrm{III}) 45.09 \mathrm{mg} / \mathrm{g}, \mathrm{Cu}(\mathrm{II}) \\
32.74, \\
\mathrm{Zn}(\mathrm{II}) 29.61 \mathrm{mg} / \mathrm{g} .\end{array}$ & [123] \\
\hline \multirow[t]{5}{*}{ Cauliflower } & Powder $102{ }^{\circ} \mathrm{C}$ for $24 \mathrm{~h}$ & BET: $0.8905 \mathrm{~m}^{2} / \mathrm{g}$ & $\begin{array}{l}\mathrm{Pb} \text { (II): } 47.63 \mathrm{mg} / \mathrm{g}(96.06 \%) \\
\mathrm{Cd} \text { (II) } 21.32 \mathrm{mg} / \mathrm{g}(81.31 \%) . \\
\text { Recovery: } \mathrm{Pb}(\mathrm{II}) 85.67 \% \text { and } \\
\text { Cd (II) } 79.74 \% .\end{array}$ & [122] \\
\hline & Roots, slow pyrolysis, $500{ }^{\circ} \mathrm{C}, 6 \mathrm{~h}$ & $\begin{array}{l}\text { BET } 232.15 \mathrm{~m}^{2} / \mathrm{g} \\
\mathrm{V} \text { pores } 0.15 \mathrm{~cm}^{3} / \mathrm{g}\end{array}$ & $\begin{array}{c}31.5 \mathrm{mg} / \mathrm{g}(92.3 \%) \text { norfloxacin; } \\
81.3 \mathrm{mg} / \mathrm{g}(93.2 \%) \\
\text { chlortetracycline }\end{array}$ & [124] \\
\hline & $\begin{array}{l}\text { Raw cauliflower cores (CC) as } \\
\text { comparison with broccoli stalks (BS) } \\
\text { and coconut shell (CS) }\end{array}$ & N.A. & $\begin{array}{c}\mathrm{Ni}^{2+}: 3.5 \text { to } 9.9 \mathrm{mg} / \mathrm{g}, \mathrm{Zn}^{2+}: 2.9 \\
\text { to } 14.4 \mathrm{mg} / \mathrm{g}, \mathrm{Cd}^{2+}: 0.4 \text { to } \\
17.9 \mathrm{mg} / \mathrm{g} \text { and } \mathrm{Cu}^{2+}: 6.2 \text { to } \\
21.2 \mathrm{mg} / \mathrm{g} \\
\mathrm{CS}>\mathrm{CC}>\mathrm{BS}\end{array}$ & [12] \\
\hline & $\begin{array}{l}\text { Pyrolysis or carbonization, } \\
\text { temperature between ( } 500 \text { and } \\
\left.800^{\circ} \mathrm{C}\right) \text {, during }(2 \text { and } 4 \mathrm{~h}) \text {. }\end{array}$ & N.A. & $\begin{array}{c}\mathrm{Cd}^{2+}: 0.81-5.69 \mathrm{mg} / \mathrm{g}, \mathrm{Ni}^{2+}: \\
0.87-5.57 \mathrm{mg} / \mathrm{g}, \mathrm{Cu}^{2+}: \\
1.19-7.21 \mathrm{mg} / \mathrm{g} \text { and } \mathrm{Zn}^{2+}: \\
0.79-4.09 \mathrm{mg} / \mathrm{g} .\end{array}$ & [12] \\
\hline & $\begin{array}{l}\text { Chemical activation, samples } \\
\text { modifed with } \mathrm{H}_{2} \mathrm{SO}_{4}(1), \mathrm{H}_{3} \mathrm{PO}_{4}(2) \\
\qquad \mathrm{NH}_{4} \mathrm{NO}_{3}(3) \text { and } \mathrm{NH}_{3}(4)\end{array}$ & N.A. & $\begin{array}{l}\text { Heavy metals: } \\
4.47-10.13 \mathrm{mg} / \mathrm{g}(1) ; \\
0.80-5.67 \mathrm{mg} / \mathrm{g}(2) ; \\
1.41-2.58 \mathrm{mg} / \mathrm{g} \mathrm{(3);} \\
2.05-9.86 \mathrm{mg} / \mathrm{g}(4)\end{array}$ & [12] \\
\hline
\end{tabular}


With regard to the biggest crops, the potatoes register an increase in comparison with corn, soy, and wheat, or rice and the increase is significantly higher in the last decades. As an example, from 1968 to 2018, the increase in world potato crops was about $46.2 \%$ [125]. The peel waste from potatoes does not represent a valuable product, but it results in a large amount after the industrial processing, which can signify from 15 to $40 \%$ of the initial potato culture [126].

Potatoes are considered the second most wasted food ingredient [73]. Important research was carried out on potatoes wastes. Usually, the peel is valorized, as adsorbents after a preliminary treatment such as drying for a few days [114,115] or chemically activated with $\mathrm{NaOH}$ [114], $\mathrm{ZnCl}_{2}$ after pyrolysis [116], or $\mathrm{H}_{3} \mathrm{PO}_{4}$ [110,113]. All experiments indicated good efficiency removal for $\mathrm{Cu}(\mathrm{II}), \mathrm{Cd}(\mathrm{II}), \mathrm{Ni}(\mathrm{II}), \mathrm{Zn}(\mathrm{II}), \mathrm{Mn}(\mathrm{II}), \mathrm{Fe}(\mathrm{II}), \mathrm{Co}(\mathrm{II})$ heavy metals using a single element or mixture of aqueous solutions. The results were confirmed by Langmuir and Freundlich isotherm models, with the best fitting for Langmuir isotherm and the pseudo-second-order kinetic model followed [109,110]. As an overall tendency, the adsorption decreases with the increase in temperature, ionic strength, and particle size. Regarding $\mathrm{Cu}$ (II) recovery behavior, after five repeated cycles almost $99.5 \% \pm 0.35$ was desorbed after the last cycle [110,115].

After potatoes, tomatoes are the next significant crop. The global tomato production was estimated in 2019 at about 180.77 million tons [52]. From the processing industry, results in important tomato pomace quantities which are afterward disposed or used. The tomato pomace is made up of peels and seeds as well as fibrous matter and tomato extracts [123]. In 2019, the wastes quantities were about 14.9 million tons from 180.77 tons of tomatoes, with almost $60 \%$ wastes from seeds $[58,124]$. The alternative utilization of the tomato wastes could be as a functional structure for colorants, antioxidants, or other types of components with beneficial consequences on health. The tomato seeds could also represent an essential material for new products [125].

Regarding environmental application, tomato wastes were valorized as powder obtained from leaves, with good adsorption properties for $\mathrm{Ni}$ (II) according to the pseudosecond-order kinetic model and Langmuir isotherm [116]. Moreover, tomato waste was chemically activated with $\mathrm{NaOH}$ for $\mathrm{Pb}(\mathrm{II})$ adsorption with good performances of experimental data in accordance with the Freundlich isotherm and pseudo-second-order model, which shows that the process was controlled by chemisorption. Desorption studies were developed using $\mathrm{HCl}$ or $\mathrm{Na}_{2}$-EDTA [117].

From the recent FAO statistics, the global production of cabbage and other brassicas overtakes two million hectares, with almost 29 tons/ha productivity [47]. The exterior leaves represent the first by-products resulting from trimming prior to marketing the cabbage. The exterior leaves are the most exposed to contamination and are discolored due to the chemical and biochemical reactions. These are also exposed to biocides or can be affected by microbial activity, which makes them improper for consumption [126]. Cabbages leaves were studied as powder material treated at $102{ }^{\circ} \mathrm{C}$ for $24 \mathrm{~h}$ in order to adsorb $\mathrm{Pb}$ (II) and $\mathrm{Cd}$ (II) ions from synthetic solutions with good fitting data as Langmuir model and pseudo-second-order kinetic models suggested. Further, an excellent recovery efficiency was recorded-higher than $80 \%$ for both elements [118].

By processing, harvesting, or marketing activities, cauliflower generates between 45 and $60 \%(w / w)$ of waste. The recycling of cauliflower waste (especially represented by non-edible parts) represents a crucial issue. Great amounts of cabbage wastes are dumped directly on the ground, leading to a serious threat to the environment. Moreover, their incineration plays a significant part in the increase of $\mathrm{CO}_{2}$ levels [127]. Besides, bioethanol production, powder waste obtained from cauliflower was used from heavy metals removals such as $\mathrm{Pb}$ (II) and $\mathrm{Cd}$ (II) from synthetic solutions - the process is described with Langmuir and pseudo-second kinetic models [118]. By thermal treatment (pyrolysis or carbonization) the adsorption capacities of the studied material increase and ions metals such as $\mathrm{Zn}^{2+}$, $\mathrm{Ni}^{2+}, \mathrm{Cd}^{2+}$, and $\mathrm{Cu}^{2+}$ were efficiently removed from synthetic solutions [12]. 
In addition, good results were obtained by using slow pyrolysis at $500{ }^{\circ} \mathrm{C}$ for $6 \mathrm{~h}$ for cauliflower roots treatment in order to obtain a stable material for norfloxacin and chlortetracycline removal from aqueous solutions, when data were fitted with the pseudosecond-order kinetic and intra-particle diffusion model and the equilibrium experiments data were confirmed by Langmuir and Freundlich isotherm models [120]. Moreover, raw cauliflower cores were tested for $\mathrm{Ni}^{2+}, \mathrm{Zn}^{2+}, \mathrm{Cd}^{2+}$, and $\mathrm{Cu}^{2+}$ in comparison with broccoli stalks and coconut shells, the heavy metal adsorption performance being the most efficient for cauliflower [12].

Carrot represents one of the most significant crops with a global supply and with production of more than 37 million tons annually [2]. Their waste could represent a good source of natural compounds with potential health attributes and possible utilization in the pharmaceutical and food sectors. From the entire production, almost $30 \%$ is split after the primary processing as unused carrots or waste (CRW). CRW consist of out-graded carrots (split due to their form and properties) and processed scrap (crowns and tips resulted during separation). Some of them are partially used for animal feeding and the rest are landfilled [128].

Carrots wastes were also tested for $\mathrm{Cr}(\mathrm{III}), \mathrm{Cu}(\mathrm{II})$, and $\mathrm{Zn}$ (II) adsorption. It was observed that the adsorption took place within $10 \mathrm{~min}$ and the equilibrium was reached after $70 \mathrm{~min}$, with the Freundlich model well-fitting the experimental data [119].

Eco-materials from fruit waste in terms of parameters and efficiency data for some pollutants removal are presented in the table below (Table 3).

Table 3. Examples of use of vegetable wastes as adsorbents for water pollutants.

\begin{tabular}{|c|c|c|c|}
\hline Fruits & $\begin{array}{c}\text { Type of Waste/Treatment Conditions, } \\
\text { Parameters }\end{array}$ & Pollutants and Adsorption Efficiency Data & References \\
\hline Orange & Peels & $\begin{array}{c}\mathrm{Ni}(\mathrm{II}): 80 \text { to } 158 \mathrm{mg} / \mathrm{g} \text { from } 30{ }^{\circ} \mathrm{C} \\
\text { to } 50{ }^{\circ} \mathrm{C}, 96 \% \text { at } 50{ }^{\circ} \mathrm{C} \text {. } \\
\text { Desorption with } 0.05 \mathrm{M} \mathrm{HCl}: 95.83 \% \text { (column } \\
\text { system); } 76 \% \text { (batch process). Recovery studies } 89 \% \\
\text { and } 93.33 \% \text {, respectively }\end{array}$ & [129] \\
\hline Orange & Peels & As(III) 1.18 mg/g (82.45\%) & [5] \\
\hline Orange & $\begin{array}{l}\text { Peel cellulose modified with alkali (such as } \\
\mathrm{NaOH}, \mathrm{NH}_{4} \mathrm{OH}, \mathrm{Ca}(\mathrm{OH})_{2} \text { ) and acids (such as } \\
\qquad \mathrm{C}_{6} \mathrm{H}_{6} \mathrm{O}_{7} \cdot \mathrm{H}_{2} \mathrm{O}, \mathrm{H}_{2} \mathrm{C}_{2} \mathrm{O}_{4}, \mathrm{H}_{3} \mathrm{PO}_{4} \text { ) }\end{array}$ & $\begin{array}{c}\mathrm{Ni}(\mathrm{II}): 1.28, \mathrm{Co}(\mathrm{II}): 1.23, \mathrm{Zn}(\mathrm{II}): 1.21 \text { and } \mathrm{Cd}(\mathrm{II}): \\
1.13 \mathrm{~mol} / \mathrm{kg} \text {. Desorption results with } 0.05 \mathrm{~mol} / \mathrm{L} \\
\mathrm{HCl}: 87.23 \% \mathrm{Zn}(\mathrm{II}) \text {, and } 93.72 \% \mathrm{Cd}(\mathrm{II}) . \text { Desorption } \\
\text { results with } 0.1 \mathrm{~mol} / \mathrm{L} \mathrm{HCl:} 81.06 \% \mathrm{Co}(\mathrm{II}) \text { and } \\
80.11 \% \mathrm{Ni}(\mathrm{II})\end{array}$ & {$[5,130]$} \\
\hline Orange & $\begin{array}{l}\text { Peel modified with mercapto-acetic acid, } \\
\text { pretreated with } \mathrm{NaOH} \text { solution }\end{array}$ & $\mathrm{Cu}^{2+}: 70.67 \mathrm{mg} / \mathrm{g} ; \mathrm{Cd}^{2+}: 136.05 \mathrm{mg} / \mathrm{g}$ & {$[5,89]$} \\
\hline Citrus & Peel & $\begin{array}{c}\mathrm{Cd}(\mathrm{II}) \text { between } 0.5 \text { and } 0.9 \mathrm{meq} / \mathrm{g} \text {, according to } \mathrm{pH} \\
\text { values }\end{array}$ & [131] \\
\hline Orange & Peel & $\mathrm{Pb}(\mathrm{II}): 1.93 \mathrm{mmol} / \mathrm{g}(400 \mathrm{mg} / \mathrm{g} \mathrm{Pb})$ & [10] \\
\hline Orange & Peel & $\begin{array}{l}\mathrm{Pb} \text { (II) } 7.75 \mathrm{mg} / \mathrm{g}, \mathrm{Ni}(\mathrm{II}) 6.01 \mathrm{mg} / \mathrm{g} \text {, Zn(II) } 5.25 \mathrm{mg} / \mathrm{g}, \\
\mathrm{Cu} \text { (II) } 3.65 \mathrm{mg} / \mathrm{g} \text {, Co(II) } 1.82 \mathrm{mg} / \mathrm{g} \text {; pH: 4.8-5.0. }\end{array}$ & [132] \\
\hline Lemon & Peel treated at $400{ }^{\circ} \mathrm{C}$, activated with $\mathrm{H}_{3} \mathrm{PO}_{4}$ & $\mathrm{Cd} 96.4 \%, \mathrm{Ni} 67.9 \% ; \mathrm{Pb} 90.11 \%$ & [133] \\
\hline Orange & $\begin{array}{l}\text { Wastes (as dry-gel), chemical modification with } \\
\mathrm{Ca}(\mathrm{OH})_{2}(\mathrm{Ca}-\mathrm{form}) \text { and washed with } 0.1 \mathrm{M} \mathrm{HCl} \\
\text { (H-form) }\end{array}$ & $\begin{array}{c}\text { Ca-form: about } 1.1 \mathrm{~mol} \mathrm{~Pb}(\mathrm{II}), \mathrm{Cd}(\mathrm{II}) \text { and } \mathrm{Zn}(\mathrm{II}) / \mathrm{kg} \\
\text { and } 1.55 \mathrm{~mol} \mathrm{Fe}(\mathrm{III}) / \mathrm{kg} \text { and } \mathrm{H} \text {-form: } 2.64 \mathrm{~mol} \\
\mathrm{Fe}(\mathrm{III}) / \mathrm{kg} \\
\text { Efficiency removal: } 100 \% \mathrm{Fe}, 95 \% \mathrm{~Pb}, 80 \% \mathrm{Cu}, 55 \% \\
\text { Cd, } 40 \% \mathrm{Zn} \text { for } \mathrm{Ca}-\text { form } \\
\text { Efficiency removal: } 98 \% \mathrm{Fe} \text { and } \mathrm{Pb}, 80 \% \mathrm{Cu}, 60 \% \mathrm{Zn} \text {, } \\
40 \% \mathrm{Cd} \text {, for } \mathrm{H} \text {-form }\end{array}$ & [134] \\
\hline
\end{tabular}


Table 3. Cont

\begin{tabular}{|c|c|c|c|}
\hline Fruits & $\begin{array}{l}\text { Type of Waste/Treatment Conditions, } \\
\text { Parameters }\end{array}$ & Pollutants and Adsorption Efficiency Data & References \\
\hline Orange & $\begin{array}{l}\text { Modified orange peel with methyl } \\
\text { acrylate }\end{array}$ & $\begin{array}{c}\mathrm{Cu}(\mathrm{II}): 289.0 \mathrm{mg} / \mathrm{g}, \mathrm{pH} 6.0,94.6 \% \text { Regeneration: } \\
4 \text { cycles }(94.6 \% \text { to } 85.2 \% \text { at the last cycle })\end{array}$ & [88] \\
\hline Orange & Saponified and modified peel with citric acid & $\begin{array}{l}\mathrm{Cd}(\mathrm{II}): 0.90 \mathrm{~mol} / \mathrm{kg} \\
\text { The desorption rate: } 94 \%, 0.15 \mathrm{~mol} / \mathrm{L} \mathrm{HCl}\end{array}$ & {$[5,135]$} \\
\hline Orange & Powdered peels & $\begin{array}{c}\text { Congo Red: } 22.4 \mathrm{mg} / \mathrm{g}, \mathrm{pH} 5.0,76.6 \% \\
\text { Procion orange: } 1.3 \mathrm{mg} / \mathrm{g}, \mathrm{pH} 3.0,49 \% \\
\text { Rhodamine-B: } 3.22 \mathrm{mg} / \mathrm{g}, \mathrm{pH} 3.0,67.5 \% \\
\text { Desorbtion studies: pH } 12 \text { for congo Red: } 37 \% \text {, } \\
\text { pH } 11 \text { for procion orange: } 78 \% \text { and } \mathrm{pH} 11 \text { for } \\
\text { rhodamine-B: } 27 \% \text {. }\end{array}$ & [136] \\
\hline \multirow[t]{2}{*}{ Orange } & Peel & $\begin{array}{l}\text { Acid violet } 17: 19.88 \mathrm{mg} / \mathrm{g}, \mathrm{pH} 6.3 \\
\text { Maximum removal: } 87 \% \text { at } \mathrm{pH} 2.0 \\
\text { Maximum desorption: } 60 \% \text { at } \mathrm{pH} 10.0\end{array}$ & [5] \\
\hline & & $\begin{array}{c}\text { Direct Yellow DY } 12 \text { Adsorption capacity: } \\
75.76 \mathrm{mg} / \mathrm{g} \\
\text { Efficiency removal: } 96 \%\end{array}$ & [5] \\
\hline Orange & Peel & Navy Blue 106 & [5] \\
\hline Orange & $\begin{array}{l}\text { Peel activated with } \mathrm{H}_{3} \mathrm{PO}_{4} \mathrm{BET} \text { value: } \\
\qquad 1090 \mathrm{~m}^{2} / \mathrm{g}\end{array}$ & $\begin{array}{c}\text { methylene blue and rhodamine B } \\
\text { (114 mmol/g MB and } 1.23 \mathrm{mmol} / \mathrm{g} \text { RhB for } \\
\text { Langmuir-Freundlich models) }\end{array}$ & {$[5,137]$} \\
\hline Orange & Peel & $\begin{array}{c}\text { Toluidine blue (TB): } 314.3 \mathrm{mg} / \mathrm{g} \text {. Removal: } 60 \% \text { at } \\
\text { pH } 3.5\end{array}$ & [5] \\
\hline Orange & Peel & $\begin{array}{c}\text { Direct Red 2: } 10.72 \mathrm{mg} / \mathrm{g}, 92 \% \text {, Direct Red } 80: \\
21.05 \mathrm{mg} / \mathrm{g}, 91 \% \text {, pH 2. Desorption: } 97.7 \% \text { and } 93 \% \\
\text { respectively, pH } 2\end{array}$ & [5] \\
\hline Orange & Peel & $\begin{array}{c}\text { Carbofuran: } 84.49 \mathrm{mg} / \mathrm{g} \text { at } 30{ }^{\circ} \mathrm{C}, 44.54 \% \text { for } \\
20 \mathrm{mg} / \mathrm{L}\end{array}$ & [138] \\
\hline Orange & Peel & Furadan $161.29 \mathrm{mg} / \mathrm{g}$ & [139] \\
\hline Orange & Peel chemical activated with $\mathrm{KCl}$ & $\begin{array}{c}\mathrm{Cu}^{2+}: 59.77 \mathrm{mg} / \mathrm{g}, \mathrm{Cd}^{2+}: 125.63 \mathrm{mg} / \mathrm{g}, \mathrm{Pb}^{2+} \\
141.84 \mathrm{mg} / \mathrm{g}, \mathrm{Zn}^{2+} 45.29 \mathrm{mg} / \mathrm{g} \text { and } \mathrm{Ni}^{2+} 49.14 \mathrm{mg} / \mathrm{g} . \\
\text { Efficinecy, after } 10 \text { cycles: } 97 \%\left(\mathrm{Cu}^{2+}\right), 90 \%\left(\mathrm{Cd}^{2+}\right) \\
\text { and } 99 \%\left(\mathrm{~Pb}^{2+}\right) .\end{array}$ & {$[5,140]$} \\
\hline Orange & $\begin{array}{l}\text { Peel powder (OPP) modified with magnetic } \\
\text { nano-adsorbent (MNP-OPP) BET value: OPP } \\
47.03 \mathrm{~m}^{2} / \mathrm{g} \text { and MNP-OPP } 65.19 \mathrm{~m}^{2} / \mathrm{g} \text {. }\end{array}$ & $\begin{array}{c}\mathrm{Cd}^{2+}: 76.92 \mathrm{mg} / \mathrm{g} \mathrm{MNP}-\mathrm{OPP} \\
\text { In case of electroplating effluent: } 55.38 \mathrm{mg} / \mathrm{g}(82 \%) \\
\mathrm{Cd}^{2+} .\end{array}$ & [5] \\
\hline Orange & $\begin{array}{l}\text { Peel (OP) and by polymerization with } \\
\text { formaldehyde (OPF) }\end{array}$ & 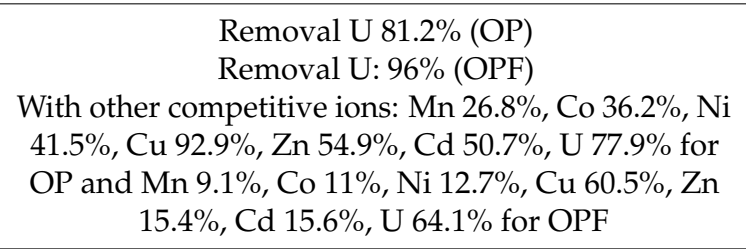 & [141] \\
\hline Pomelo & Peels chemically acrivated $\left(\mathrm{ZnCl}_{2}\right)$ & $\begin{array}{c}\mathrm{Pb}^{2+}, \mathrm{Cu}^{2+} 90 \% \text { from WWT, } 21.1 \mathrm{mg} / \mathrm{g} \text { from } \\
\text { synthetic solution }\end{array}$ & {$[142,143]$} \\
\hline Pomelo & Peel (PP) and depectinated pomelo peel (DPP) & $\begin{array}{c}\mathrm{Cu}^{2+} \text { adsorption capacity for PP } 19.7 \mathrm{mg} / \mathrm{g} \text { and DPP } \\
21.1 \mathrm{mg} / \mathrm{g} \text { at } \mathrm{pH} 4\end{array}$ & {$[142]$} \\
\hline Pomelo & Peel wastes & Methylene blue: $133 \mathrm{mg} / \mathrm{g}(83 \%)$. & {$[5,144]$} \\
\hline
\end{tabular}


Table 3. Cont.

\begin{tabular}{|c|c|c|c|}
\hline Fruits & $\begin{array}{c}\text { Type of Waste/Treatment Conditions, } \\
\text { Parameters }\end{array}$ & Pollutants and Adsorption Efficiency Data & References \\
\hline Pomelo & $\begin{array}{l}\text { Peel wastes BET value } 1357.21 \mathrm{~m}^{2} / \mathrm{g} \text {. } \\
\text { V tot pores } 1.61 \mathrm{~cm}^{3} / \mathrm{g}\end{array}$ & $\begin{array}{c}\text { Malachite green: } 178.43 \mathrm{mg} / \mathrm{g} .(95.06 \%), \mathrm{pH} 8.0 . \\
\text { Recovery after } 4 \text { cycles } 96.35 \%\end{array}$ & {$[5,145]$} \\
\hline Grapefruit & peels activated $\mathrm{ZnCl}_{2}$ & $\mathrm{~Pb}^{2+} 12.73 \mathrm{mg} / \mathrm{g}(90 \%)$ & [5] \\
\hline Grapefruit & Peels, raw and protonated & $\begin{array}{c}\mathrm{Cd}^{2+}: 1.7 \mathrm{meq} / \mathrm{g} \text { (raw material) and } 2.2 \mathrm{meq} / \mathrm{g} \\
\text { (protonated peels) }\end{array}$ & [5] \\
\hline \multirow[t]{3}{*}{ Grapefruit } & Peels & $\begin{array}{c}\text { crystal violet }(\mathrm{CV}): 254.16 \mathrm{mg} / \mathrm{g} . \text { Efficiency } 96 \% \\
\text { Recovery: } 98.25 \% \text { using } 1 \mathrm{M} \mathrm{NaOH} \text {, in } \\
\text { repeated cycles }\end{array}$ & {$[5,146]$} \\
\hline & & $\mathrm{Cd}(\mathrm{II}) \mathrm{Ni}(\mathrm{II}) 42.09$ and $46.13 \mathrm{mg} / \mathrm{g}$ & {$[5]$} \\
\hline & & U (VI): 140.79 mg/g. Recovery after 3 cycles: $80 \%$ & [147] \\
\hline Grapefruit & $\begin{array}{l}\text { Peel (GP) and by polymerization with } \\
\text { formaldehyde (GPF) }\end{array}$ & $\begin{array}{c}\text { Removal U 77.3\% (GP) } \\
\text { Removal U: 73.4\% (GPF) } \\
\text { With other competitive ions: Mn 27.6\%, Co 38.3\%, Ni } \\
\text { 43.9\%, Cu 94.2\%, Zn 56.6\%, Cd 54.3\%, U } 83.3 \% \text { for } \\
\text { GP and Mn } 11.5 \% \text {, Co } 14.2 \% \text {, Ni } 16.4 \%, \mathrm{Cu} 65.6 \% \text {, Zn } \\
21.9 \% \text {, Cd } 20.3 \% \text {, U 71\% for GPF }\end{array}$ & [141] \\
\hline Lemon & Peels & $\begin{array}{c}\text { Methyl orange (MO) } 50.3 \mathrm{mg} / \mathrm{g} \text {, Congo red (CR) } \\
34.5 \mathrm{mg} / \mathrm{g}\end{array}$ & [148] \\
\hline Lemon & $\begin{array}{l}\text { Peels chemical activation }(1 \mathrm{M} \mathrm{HCl} \text { and } 1 \mathrm{M} \\
\qquad \mathrm{NaOH})\end{array}$ & $\begin{array}{l}\text { Cutting oil Adsorption capacity } 8.896 \mathrm{mg} / \mathrm{g}, 94 \% \text { at } \\
\qquad 5 \mathrm{~g} / \mathrm{L} \text { lemon peel }\end{array}$ & [149] \\
\hline Lemon & peels waste & Co: $22 \mathrm{mg} / \mathrm{g}$ & [5] \\
\hline Lemon & Cold alkali peel & $\mathrm{Pb}^{2+}: 630 \mathrm{mg} / \mathrm{g}$ & {$[5]$} \\
\hline Lemon & Peels waste & Cd: $11.24 \mathrm{mg} / \mathrm{g}$ and efficiency removal $80.8 \%$ & [5] \\
\hline $\begin{array}{l}\text { Sweet } \\
\text { lime }\end{array}$ & peels & $\mathrm{Cu}(\mathrm{II}): 37.45 \mathrm{mg} / \mathrm{g}$ at $293 \mathrm{~K}$ & [150] \\
\hline Lemon & Protonated peels & $0.9 \mathrm{meq} / \mathrm{g}$ at $\mathrm{pH} 5$ & [131] \\
\hline \multirow[t]{6}{*}{ Bananas } & Powder banana peels & $\begin{array}{c}5.71 \mathrm{mg} / \mathrm{g} \mathrm{Cd}(\mathrm{II}) \text { and } 2.18 \mathrm{mg} \mathrm{Pb}(\mathrm{II}) / \mathrm{g} \\
\text { Maximum removal: } 89.2 \% \text { for } \mathrm{Cd}(\mathrm{II}) \text { and } 85.3 \% \text { for } \\
\mathrm{Pb}(\mathrm{II})\end{array}$ & [151] \\
\hline & $\begin{array}{l}\text { Untreated banana peels (1), } \\
\text { alkali-hydrolyzed banana peels (2), } \\
\text { acid-hydrolyzed banana } \\
\text { peels (3), and bleached Banana peels (4) }\end{array}$ & $\begin{array}{c}\text { 1: } \mathrm{Cr}(\mathrm{VI}): 45 \% \text { and } \mathrm{Mn}(\mathrm{II}) 51 \%, 2: \mathrm{Cr}(\mathrm{VI}) 87 \% \text { and } \\
\mathrm{Mn}(\mathrm{II}) 90 \%, 3: \mathrm{Cr}(\mathrm{VI}) 67 \% \text { and } \mathrm{Mn}(\mathrm{II}) 74 \%, 4: \mathrm{Cr}(\mathrm{V}) \\
40 \% \text { and } \mathrm{Mn}(\mathrm{II}) 67 \% .\end{array}$ & [5] \\
\hline & Banana peels wastes & $\begin{array}{c}\text { phenolic compounds: } 689 \mathrm{mg} / \mathrm{g} \\
\text { Desorbtion at neutral } \mathrm{pH} \text { water }(\mathrm{pH} 7.3) 0.17 \mathrm{~g} / \mathrm{g} \text {, } \\
\text { acetic acid (pH 1.2) } 0.30 \mathrm{~g} / \mathrm{g} \text { and alkaline water } \\
\text { (pH 12) } 0.12 \mathrm{~g} / \mathrm{g} \text { phenolic compounds }\end{array}$ & {$[5,82]$} \\
\hline & $\begin{array}{l}\text { Banana peels (NBP) and modified with caustic } \\
\text { soda (ABP) }\end{array}$ & $\begin{array}{c}\text { methylene blue adsorption capacities: } 19.671 \mathrm{mg} / \mathrm{g} \\
\text { (ABP) and } 18.647 \mathrm{mg} / \mathrm{g}(\mathrm{NBP}) \\
\text { ABP: } 98.93 \% \text { for } \mathrm{pH} 4-8\end{array}$ & [152] \\
\hline & Banana peel waste & $\begin{array}{c}\text { atrazine } 93.8 \% \text { and ametryne } 95.2 \% \text {. Desorption of } \\
\text { ametryne: } 31.5 \% \text { and } 47.5 \% \text { for atrazine }\end{array}$ & [153] \\
\hline & $\begin{array}{c}\text { Charred } \\
\text { banana peels chemical activated with } \mathrm{H}_{3} \mathrm{PO}_{4}\end{array}$ & $\begin{array}{l}\text { Atrazine: } 14 \mathrm{mg} / \mathrm{g} . \\
90-99 \% \text { atrazine removal }\end{array}$ & [154] \\
\hline
\end{tabular}


Table 3. Cont.

\begin{tabular}{|c|c|c|c|}
\hline Fruits & $\begin{array}{c}\text { Type of Waste/Treatment Conditions, } \\
\text { Parameters }\end{array}$ & Pollutants and Adsorption Efficiency Data & References \\
\hline & Banana peel treated with acid, alkali, and water & $\begin{array}{l}\text { Adsorption capacities: } 7.97\left(\mathrm{~Pb}^{2+}\right), 6.88\left(\mathrm{Ni}^{2+}\right), 5.80 \\
\left(\mathrm{Zn}^{2+}\right), 4.75\left(\mathrm{Cu}^{2+}\right) \text {, and } 2.55 \mathrm{mg} / \mathrm{g}\left(\mathrm{Co}^{2+}\right) \text { at } \mathrm{pH} \text { of } \\
\text { around } 5.4-5.8\end{array}$ & {$[5,132]$} \\
\hline & $\begin{array}{l}\text { Natural banana peel (1), } \\
\text { methylated banana peel (2) }\end{array}$ & $\begin{array}{l}\text { Palm oil mill effluent. (1)97 mg/g color, } 25 \mathrm{mg} / \mathrm{g} \\
\text { TSS, and } 90.5 \mathrm{mg} / \mathrm{g} \text { COD. (2); } 137.5 \mathrm{mg} / \mathrm{g} \text { color, } \\
28.5 \mathrm{mg} / \mathrm{g} \text { TSS and } 93 \mathrm{mg} / \mathrm{g} \text { COD. }\end{array}$ & [155] \\
\hline & $\begin{array}{l}\text { Carbonized banana peels, chemical activation } \\
\text { with } \mathrm{H}_{2} \mathrm{SO}_{4}\end{array}$ & $\begin{array}{l}\text { Removal for } \mathrm{Pb}: 33.3 \% \\
\text { Removal for } \mathrm{Zn}: 27.3 \% \\
\text { Removal for } \mathrm{Cr}: 77.8 \%\end{array}$ & [156] \\
\hline \multirow[t]{3}{*}{ Apples } & $\begin{array}{l}\text { Apple juice residue chemical activated with } \\
\qquad \mathrm{NaOH}\end{array}$ & $\begin{array}{c}\mathrm{Pb}(\mathrm{II}) \text { Adsorption capacity: } 108 \mathrm{mg} / \mathrm{g} \\
\text { Removal: Cca } 90 \% \\
\text { Desorbtion studies: } \mathrm{HCl}: 59,647 \%, \mathrm{Na}_{2} \text {-EDTA: } \\
99,809 \% \\
\text { BET values before and after activation: } 7.04 \text { and } \\
11.13 \mathrm{~m}^{2} / \mathrm{g} \text {. Vpores: } 8.34 \times 10^{-3} \mathrm{cc} / \mathrm{g}\end{array}$ & [117] \\
\hline & Zr immobilized apple peel & $\begin{array}{c}\mathrm{AsO}_{2}{ }^{-}: 15.64 \mathrm{mg} / \mathrm{g}, \mathrm{AsO}_{4}{ }^{3-} 15.68 \mathrm{mg} / \mathrm{g}, \mathrm{Cr}_{2} \mathrm{O}_{7}{ }^{2-} \\
25.28 \mathrm{mg} / \mathrm{g} \text {, and } \mathrm{PO}_{4}{ }^{3-} 20.35 \mathrm{mg} / \mathrm{g} . \\
\text { Desorbtion } 90 \% \text { of pollutants } \mathrm{pH} 12 \text {, after } 10 \mathrm{~min}\end{array}$ & [157] \\
\hline & $\begin{array}{l}\text { Apple residue (AR) and Apple Phosphate } \\
\text { residue }(P) \text {, and Apple Xanthate residue (CLX) }\end{array}$ & $\begin{array}{c}\text { Cu Zn Ni: } 403027 \text { mg/g P-AR } \\
\text { Cu Zn Ni: } 251512 \text { mg/g CLX-AR } \\
\text { Cu Zn NI: } 1065 \text { mg/g AR }\end{array}$ & [13] \\
\hline Grapes & Grape skins & $\mathrm{Cd}^{2+}$ metal uptake capacity $1.20 \mathrm{meq} / \mathrm{g}$ & [131] \\
\hline Mango & Mango peel waste & $\begin{array}{c}\mathrm{Cu}^{2+} 46.09 \mathrm{mg} / \mathrm{g}, \mathrm{Ni}^{2+} 39.75 \mathrm{mg} / \mathrm{g} \\
\mathrm{Zn}^{2+} 28.21 \mathrm{mg} / \mathrm{g} \\
\text { Removal: } 89.02 \%, 76.40 \% \text {, and } 67.27 \% \text { for } \mathrm{Cu}(\mathrm{II}) \text {, } \\
\mathrm{Ni(II)} \text {, and } \mathrm{Zn}(\mathrm{II}) \\
\text { genuine electroplating effluent: } \mathrm{Cu}(\mathrm{II}) \mathrm{cca} 90 \%, \mathrm{Ni}(\mathrm{II}) \\
\text { cca } 80 \%, \mathrm{Zn}(\mathrm{II}) \text { cca } 80 \%\end{array}$ & [158] \\
\hline
\end{tabular}

Citrus comprises a large variety of fruits and some wastes of these are used with high efficiency for heavy metals removal. Usually, the solid waste of citrus consists of peel, seeds, and leaves, from which peel represents the most important waste. Only peel waste represents about $50 \%$ of the wet fruit mass. Due to their valuable compounds such as flavonoids, essential oils, polyphenols, carotenoids, fiber, sugars, ascorbic acid, and other trace elements, peel waste has huge economic value [1].

Among these, according to the United States Department of Agriculture Foreign Agricultural Service, global orange production for 2020/21 is estimated to grow by 3.6 MMT in comparison to the previous year, and this production will rise to 49.4 MMT. Combined with this, consumption, processing, and juice production are different and depend on fresh export, weather, and the increase in harvested areas [159].

Data show that the peels were intensively used. Orange peel, as a primary waste, contains flavonoids which serve a role as chelators for metals. Unmodified orange peels have been investigated for ion metals such as $\mathrm{Ni}(\mathrm{II}), \mathrm{Co}(\mathrm{II}), \mathrm{Zn}(\mathrm{II}), \mathrm{Pb}(\mathrm{II})$, and $\mathrm{Cd}(\mathrm{II})$, and metalloids such as As(III) $[5,129,131,132,140]$. Ni(II) removing from synthetic solutions similar to electroplating wastewater by using orange peels as an adsorbent was successfully carried out in three cycles of adsorption-desorption, in which the adsorption process pursues first-order kinetics. Schiewer and coworkers observed that adsorption kinetics depend on size material with similar performance with synthetic cation exchange resins [10].

Modified orange peels under alkaline or acidic medium were compatible for $\mathrm{Cd}(\mathrm{II})$, $\mathrm{Zn}(\mathrm{II}), \mathrm{Co}(\mathrm{II})$, and $\mathrm{Ni}(\mathrm{II})$ retention-the results having a good correlation with the Lagergren first-order kinetics model, in comparison with unmodified orange peels. The Langmuir 
and Freundlich adsorption isotherm models were in accordance with the experimental data for all the metal ions. According to the desorption results, the ion exchange process is involved in the adsorption process [5,130].

Also, orange peel modified with mercapto-acetic acid, after treatment with $\mathrm{NaOH}$ solution was used for $\mathrm{Cu}(\mathrm{II})$ and $\mathrm{Cd}(\mathrm{II})$ adsorption-desorption studies, with good results after more than five cycles of re-utilization. The process was developed in accordance with chemical adsorption followed by a pseudo-second-order kinetic model [5,89]. Another modification of orange peel was made by cross-linking with methyl acrylate in order to enhance the adsorption of $\mathrm{Cu}(\mathrm{II})$ ions from synthetic aqueous solution and electroplating wastewater. The material had a good regeneration capacity corresponding to four adsorption-desorption cycles, and the best fit for the equilibrium date was obtained with the Langmuir isotherm model [88]. In addition, a modified orange peel powder with magnetic nano-powder for $\mathrm{Cd}$ (II) adsorption from an electroplating simulated wastewater and aqueous solutions was successfully carried out. It was highlighted that the adsorption process follows a pseudo-second-order kinetic model [5].

Orange and grapefruit peels adsorb high quantities of uranium (U) from non-salty water. Orange and grapefruit peel incline to increase their uranium adsorption selectivity with other competitive ions: $\mathrm{Mn}, \mathrm{Co}, \mathrm{Ni}, \mathrm{Cu}, \mathrm{Zn}, \mathrm{Cd}$ [141].

Orange wastes could act as ion exchangers when are modified with $\mathrm{Ca}(\mathrm{OH})_{2}(\mathrm{Ca}-$ form) and $\mathrm{HCl}$ (H-form), respectively. Efficiency removal is highest for $\mathrm{Fe}(100 \%)$ and $\mathrm{Pb}(80 \%)$, and under $50 \%$ for $\mathrm{Cd}(\mathrm{II}), \mathrm{Cu}(\mathrm{II}), \mathrm{Zn}(\mathrm{II})$. with specific Langmuir-type adsorption [134].

Orange peels powder was used for the removal of different dyes in order to evaluate the adsorption capacity mechanism and establish a proper kinetic model. For example, Congo red, procion orange, acid violet 17 , direct yellow, toluidine blue, direct blue, direct navy blue, direct red, and rhodamine B were tested in synthetic solutions at acidic $\mathrm{pH}$ values. As it is observed in Table 3, good adsorption capacities were obtained and as well as different regeneration capacities for the adsorbents as a function of the $\mathrm{pH}$ of the aqueous solutions and the structure of the dyes. Usually, both Langmuir and Freundlich isotherms were tested with good correlation data for these studies $[5,136]$.

According to the preparation methods of these wastes, one procedure consists of the chemical activation of peel. Good results were obtained when $\mathrm{H}_{3} \mathrm{PO}_{4}$ was used for the removal of methylene blue and rhodamine $B$ from synthetic solutions [5].

Organic compounds, especially biocides, were analyzed at contact with orange peel. It was observed that $\mathrm{NaCl}$ decreased the adsorption capacity for carbofuran from an aqueous solution, and a pseudo-second-order kinetic model described the kinetic mechanism [138].

$\mathrm{Xu}$ and coworkers established that both Langmuir and Freundlich models are in accordance with the adsorption data for furadan from aqueous solution [139].

Regarding lemons, the United States Department of Agriculture (USDA) indicates that global production in 2020/21 will slowly decrease by about 8.3 million tons due to the lower production in Argentina and the United States, in comparison to the European Union where weather conditions are favorable for lemon production [159]. Lemon peels are valuable materials for cosmetics, food, or biomedical applications and in the last years, numerous studies were developed in water remediation using lemon waste as peels. These wastes were used as a powder or after thermal treatment at $400{ }^{\circ} \mathrm{C}$ and chemical activation with $\mathrm{H}_{3} \mathrm{PO}_{4}$ for $\mathrm{Cd}(\mathrm{II}), \mathrm{Pb}$ (II), or $\mathrm{Co}$ (II) removal [5,133]. Lemon peels activation under acidic or basic conditions were studied for the cutting oil from an oil-in-water emulsion [149]. $\mathrm{Pb}(\mathrm{II})$ ions were successfully removed using cold alkali lemon peels [5], while Cd(II) when lemon peels are activated to develop some protonated sites on their surface [131]. Sweet lime peels were used for $\mathrm{Cu}$ (II) adsorption, experimental data giving the best correlation with the pseudo-second-order kinetics [150].

Methyl orange and Congo Red were tested as contaminants presented in an aqueous solution; data indicated a pseudo-first-order kinetic model when lemon peels are used. Also, real wastewaters, with basic $\mathrm{pH}$ and organic dye loads were studied with high efficiency of removal [5]. 
USDA and FAO do not make a difference between grapefruit and pomelo as commodities and the global production in 2020/21 is anticipated to increase by 6.9 million tons as a consequence of the favorable weather and expanded area in China and Mexico [159]. Within these figures, a huge quantity of wastes appears as a result of consumption and processing.

Pomelo peel wastes were tested for methylene blue, crystal violet, and malachite green adsorption from synthetic solution with high efficiency as is presented in Table 3 [144-146].

Heavy metals as $\mathrm{Pb}(\mathrm{II}), \mathrm{Cd}(\mathrm{II}), \mathrm{Ni}(\mathrm{II})$, and $\mathrm{Cu}(\mathrm{II})$ were investigated at contact with pomelo peel untreated and depectinated and chemical activated with $\mathrm{ZnCl}_{2}$ and protonated, with efficiency in wastewater decontamination and synthetic solutions where the Langmuir isotherm and the pseudo-second-order rate model correspond to the adsorption process $[5,142]$.

Grapefruit peel and polymerization product with formaldehyde were used for U(VI) removal, as a radioactive element, and for other competitive ions together with uranium, such as: $\mathrm{Mn}, \mathrm{Co}, \mathrm{Ni}, \mathrm{Cu}, \mathrm{Zn}$, and $\mathrm{Cd}$. Similar studies were taken onto the orange peel. It was observed that orange and grapefruit peel lead to an increase the uranium adsorption selectivity $[141,147]$.

Bananas are one of the most used up and low-cost fruit in the world. In 2019, global exports of bananas reached an estimated 21 million tons, meaning a $10.2 \%$ increase compared with 2018 [160]. Rana et al. indicated that banana plants have no use after harvesting the fruit, excepting bioethanol, citric acid, lactic acid, cosmetics, fibers, bio-films, paper, bio-plastic, bio-electricity, etc. Besides these banana peels are also used as bio-sorbent for nitrites removal from drinking water, and also have antifungal and antibiotic properties [161].

For example, powder banana peels are used for heavy metals removal. $\mathrm{Pb}(\mathrm{II}), \mathrm{Cd}(\mathrm{II})$, $\mathrm{Zn}(\mathrm{II}), \mathrm{Ni}(\mathrm{II}), \mathrm{Cu}(\mathrm{II}), \mathrm{Co}(\mathrm{II}), \mathrm{Cr}(\mathrm{VI}), \mathrm{Mn}(\mathrm{II})$ from aqueous solutions can be removed using untreated, carbonized, chemically activated as alkali-hydrolyzed, acid-hydrolyzed, and bleached banana peels. Usually, the Langmuir and Freundlich isotherms describe the adsorption process, with specific performances for each metal [5,132,151,156].

Different banana peels substrates were used (natural peel, methylated, or as activated carbon) were tested for pollutants removal from a palm oil mill effluent [155]. Parameters such as color, TSS (total solid substances), COD (chemical oxygen demand), tannin, and lignin were investigated. The maximum percentage of removal was registered on banana peel-activated carbon, at a $\mathrm{pH}$ of 2 . The pseudo-second-order model was fitted indicating that the biosorption process is based on the chemisorption mechanism.

In addition, methylene blue was studied using banana peels unmodified and modified with caustic soda in aqueous solutions, with high efficiency and using the Langmuir and Freundlich isotherms models [152].

Phenolic compounds (hydroxytyrosol and tyrosol), atrazine, and ametrine were tested in order to evaluate the adsorption capacity in neutral $\mathrm{pH}$ water, river, and treated water samples. Langmuir, Freundlich, and Redlich-Peterson isotherm models provided good correlations for specific pollutants and good adsorption capacity, with chemisorption interactions at desorption experiment in case of phenolic compounds, as the values indicated in Table $3[5,82,153,154]$.

According to the STATISTA site, in 2019 the global apple production was about 87.24 MMT in comparison with 2017 when the production was about 83.14 million tons [162]. Apple processing industries are responsible for high quantities of wastes as solids and liquids. The solids waste is known as "apple pomace", and represents a combination of seeds, pulp, and skin, resulted from the concentrated apple juice, sweets, and jam production. Apple pomace is highly biodegradable, being a real threat to the environment, thus $20 \%$ is recovered as animal feed and $80 \%$ is landfilled, composted, or incinerated. Each option represents an important source of released greenhouse gases [163].

Apple juice residue chemical activated with $\mathrm{NaOH}$ can be adsorbent materials for $\mathrm{Pb}$ (II). The process follows a pseudo-second-order model which shows that the process is 
controlled by chemisorption [117]. Different functionalized apple residues were tested, for example for As, $\mathrm{Cr}$ and $\mathrm{P}$ as anions species when $\mathrm{Zr}$ was immobilized on apple peel [157], apple residue untreated, apple phosphate residue and apple xanthate residue for $\mathrm{Cu}(\mathrm{II})$, $\mathrm{Zn}(\mathrm{II})$ and $\mathrm{Ni}(\mathrm{II})$ [13].

Grapes are crops that grow in all countries of the world and give economic benefits than the other crops to farmers. China had a production of about 13,083,000 tons in 2017, meanwhile, South Africa had 2,032,582 tons [164]. Referring to grapes, wine production is one of the most significant sectors, with the central yield region in Europe (Italy, Spain, France, Germany, and Portugal), America (USA, Argentina, and Chile), as well as Australia, South Africa, and China. Wine production is linked with significant quantities of both organic wastes known as grape pomace (skins, pulp, branches, seeds, grape stems, and grape leaves that summarized about $1.5 \mathrm{~kg}$ generated per liter) and wastewater (about 75\%) [165]. The wastes are connected with the production area and the physical-chemical properties of the waste vary slightly [3]. Other residues are represented by emissions of greenhouse gases $\left(\mathrm{CO}_{2}, \mathrm{VOC}\right.$, etc.), and inorganic wastes (bentonite clay, diatomaceous earth, and perlite) [165]. Chouchouli and coworkers indicated in their study that approximately 14.5 million tons of grape by-products are yield annually in Europe [166].

As an option for reuse of some wastes, grape skins were used for $\mathrm{Cd}(\mathrm{II})$ in aqueous solutions, but thanks to their low stability at $\mathrm{pH} 5$, after $2 \mathrm{~h}$ of contact, these types of wastes gained high attention in biomedical and cosmetics applications [131].

Mangos are intensively used as fruits all over the world. Global production (including mangos, mangosteens, and guavas) reached 55.85 MMT in 2019, with an increasing trend in comparison with 2018, when the production was about 53.41 MMT [167]. The FAO predicted that the global production of mango will reach 65 million tons by 2028 [79]. The solid waste resulting after production, consumption, and processing consists of peels, stones, stalk, trimmings, and fibrous material [168]. Mango peel waste was tested for $\mathrm{Cu}(\mathrm{II})$, $\mathrm{Ni}(\mathrm{II}), \mathrm{Zn}(\mathrm{II})$ removal from aqueous solutions and electroplating wastewaters. Adsorption data were following the Langmuir adsorption isotherm model [158].

\section{Disadvantages-Research Gaps}

Besides the real advantages regarding converting some fruit and vegetable wastes into valuable eco-materials with high efficiency in pollutants removal from water and wastewaters, based on experimental data, the researchers indicated some restrictions as disadvantages in the use of these types of eco-materials as adsorbents. These features will represent the next developed research in the field that will contribute to the preparation and design of more sustainable adsorbents as eco-materials for which regeneration capacities and stability will be reliable properties. Until then, one of the restrictions is the use of untreated peel waste that increased the biochemical oxygen demand (BOD) and chemical oxygen demand (COD) values of wastewater as a consequence of soluble organic compounds dissolute from peel wastes composition [156] In the case of banana, orange, grapefruit, and apple residues the soluble substances (sugars, resins, pectins, etc.) diffuse into the water as colored substances. This structural instability, combined with their relatively low ion exchange capacity, interferes with the use of untreated eco-materials [13]. Moreover, grape residues were reported as having a tendency of dissolution at acidic $\mathrm{pH}$ [131]. One of the challenges is the immobilization of tannin and pectin with good results $[141,169]$. Even if the unmodified wastes are low-cost and available, chemically activated wastes indicated better adsorption than unmodified forms, due to the higher number of binding sites, with the possibility of ion-exchange processes and the creation of new functional groups $[13,18,42,142]$. Under these circumstances, thermal treatments, where porous and stable structures similar to activated carbon are obtained, can provide good performances without solubilization of material $[112,113,137,170-176]$. Some research, where fruit and vegetable wastes, especially peels, have been thermally treated or chemically activated, has indicated good stability and more reliable use in aqueous solutions, the results are summarized in this review. 
The literature indicates the importance of technical and economical features for lowcost adsorbents derived from agri-food wastes, often by comparison with activated carbon, with emphasizing the benefits and limits of agri-food wastes as adsorbents regarding the cost of preparation and regeneration $[23,84-86,177]$. A very important aspect regarding the chemical and thermal modifications for agri-food wastes, especially for fruits and vegetables, refers to the final price of the new modified materials, after treatments. The high prices reduce their advantages over conventional adsorbents (unmodified wastes) and lead to environmental pressures at the end of their life cycle. The new modified materials could be converted into toxic waste. As in other cases, research into the design and implementation of a new and stable material focuses on its functionality rather than the economic aspect. Fruit and vegetable waste as eco-materials with adsorption properties expose costs related to many factors: availability, source, treatment conditions, recycle, and lifetime use. In their work, Pyrzynska and coworkers stated that an adsorbent could be an option when regeneration is possible for sustaining a continuous flow of the treated effluent in order to decrease the cost of operation and overall maintenance [42]. Thus, the cost-benefit analysis is the most important step when agri-food waste becomes the subject of valorization as eco-materials with adsorbent properties.

As a potential improvement of environmental protection, eco-materials derived from agri-food wastes contribute to the diminishing of the environmental burden from a regeneration perspective. The choice of an adsorbent is based on these aspects. Further, the potential of its regeneration induces a reduction in costs for the whole process. In order to be available for regeneration, the mechanical strength of the waste and the type of removal mechanism are very important. According to the literature, all adsorbents have an ion-exchange system especially for heavy metals and nutrients, while the most appropriate conditions are mild to strongly acidic media.

Acid solutions are the most common wastes in all industries and could be reused as regeneration agents. In industry, the scope of regeneration is based on valuable metals or other the recovery of components combined with the economic aspect of adsorbent reuse. Most research was developed in adsorption capacities and mechanisms with low interest for regeneration studies. In the latest years, this aspect was developed in different studies whilst emphasizing the importance of regeneration and final use disposal of spent adsorbents as potentially dangerous wastes [41]. The regeneration of the adsorbents could be a valuable benefit, their high potential of reusability leading to cost, disposal, and natural resources reductions.

Besides these issues, another challenge remains the transfer to the laboratory scale at the pilot and industry level. Most of the studies published in the literature, as they are presented in Table 2; Table 3, refer to experiments at the lab scale, using synthetic solutions. The lack of information on pilot scale or industrial level studies remains a drawback for real applications, this aspect being a common approach also for the other adsorbents or water treatment materials.

\section{Efficiency and Cost Comparison}

Regarding the evaluation of the adsorption process as a viable option for water treatment, two basic components have to be evaluated, namely efficiency (adsorption capacity) and adsorbent cost [41]. If agri-food wastes are used as adsorbents, usually, the efficiency is related to a commercial adsorbent (activated carbon). Regarding the adsorbent costs, some aspects have to be estimated, namely, availability, source, preparation method, reuse/recycling method, transport distances, and life-cycle assessment. However, the literature indicates lower costs for the adsorbents as a result of agri-food wastage, without providing exact costs [20,178-180]. In the EU, is it estimated that 88 million tons of food waste are generated yearly with related costs of about 143 billion euros [26]. Future investigations have to be developed with a focus on the cost and economic benefits correlated with the eco-materials performance. As entry data, commercially activated carbon and ion exchangers prices and waste costs from some types of commodities have 
to be analyzed. For example, the price of activated carbon is over EUR 3.0 due to the adsorption capacity and adsorbent costs [41]. At first sight, the price for the dried citrus peels (EUR 300-600/ton) is about $100 \times$ lower than for ion exchangers' price (EUR 30,00050,000/ton) [131].

Moreover, it is important to emphasize that water quality changes with consumption models and new pollutants classes could appear as interferences; so the quantity and efficiency could be changed with a direct influence on the adsorbent costs. Between the lab- scale models and industrial treatment plants, the pilot-scale experiments must be undertaken in order to establish adequate operations, maintenance steps, labor costs, and also local circumstances.

A very important aspect of today's environment is the threat from GHG emissions. The production of fruits and vegetables as agri-food commodities generates low GHG emissions, due to diesel and nitrogen fertilizers, with the lowest levels for potatoes and other roots [47].

\section{Conclusions and Future Recommendations}

Fruits and vegetables as hot-spot agri-food commodities are produced in abundance and have a huge potential for waste reuse in accordance with the circular economy concept and with a high impact on the quality of life. Their wastes are valuable for the next generation of eco-materials used in the environment, energy, biomedical application, pharmaceutics, and cosmetics industries. Good results were obtained using the fruit and vegetable wastes as major agri-food wastes for heavy metal and organic pollutants removal from aqueous solutions in laboratory-scale experiments, with the possibility in the future to apply this at the industrial level. The valorization of these wastes as eco-materials with adsorbent properties offers new perspectives for water sustainability.

The most produced fruits and vegetables all over the world are responsible for a huge quantity of waste. Usually, by landfilling these wastes a significant quantity of GHG is produced. In order to decrease the carbon footprint, their use as adsorbent materials at the nexus of water and energy represent a mandatory alternative. Moreover, these eco-materials are cost effective and easily available.

This paper summarizes, from the vast literature, the main characteristics of their application for heavy metals, organics, and micropollutants removal from waters. Only a few examples were identified with a focus on wastewaters.

Until now, the lack of information regarding pilot-scale systems and industrial transfer represents the central disadvantage of using these cost-effective eco-materials as adsorbents for treatment technologies. Future studies will provide the proper solutions for these valuable materials. The following research is important to be developed: surface chemistry characterization of adsorbents and mechanism for a better understanding of adsorption mechanisms in wastewater treatment; pilot-scale experiments; cost benefits calculation before industrial implementation; efficiency of agri-food eco-materials as adsorbents with their integration in overall water treatment systems, including biological interactions; and end of use of these eco-materials.

Author Contributions: Conceptualization, E.M. and M.R.; methodology, C.P.; software, A.M.P. and A.A.T.; validation, E.M., C.O. and L.B.; formal analysis, C.B. and R.V.; investigation, A.M.P., M.R., C.O., C.B. and C.P.; resources, C.P.; data curation, A.A.T. and R.V.; writing, A.M.P. and E.M.; writing and supervision, R.V., M.R. and C.O. All authors have read and agreed to the published version of the manuscript.

Funding: This work was supported by a grant of the Romanian Ministry of Research and Innovation, CCCDI-UEFISCDI, project number 26PCCDI/01.03.2018, “Integrated and sustainable processes for environmental clean-up, wastewater reuse and waste valorization" (SUSTENVPRO), within PNCDI III.

Institutional Review Board Statement: Not applicable.

Informed Consent Statement: Not applicable. 
Data Availability Statement: Data sharing not applicable.

Conflicts of Interest: The authors declare no conflict of interest.

\section{References}

1. Sharma, K.; Mahato, N.; Cho, M.H.; Lee, Y.R. Converting citrus wastes into value-added products: Economic and environmently friendly approaches. Nutrition 2017, 34, 29-46. [CrossRef]

2. Šeregelj, V.; Vulić, J.; Ćetković, G.; Čanadanovć-Brunet, J.; Šaponjac, V.T.; Stajčić, S. Natural bioactive compounds in carrot waste for food applications and health benefits. Stud. Nat. Prod. Chem. 2021, 67, 307-344. [CrossRef]

3. Maicas, S.; Mateo, J.J. Sustainability of Wine Production. Sustainability 2020, 12, 559. [CrossRef]

4. Omo-Okoro, P.N.; Daso, A.P.; Okonkwo, J.O. A review of the application of agricultural wastes as precursor materials for the adsorption of per-and polyfluoroalkyl substances: A focus on current approaches and methodologies. Environ. Technol. Innov. 2018, 9, 100-114. [CrossRef]

5. Bhatnagar, A.; Sillanpää, M.; Witek-Krowiak, A. Agricultural waste peels as versatile biomass for water purification-A review. Chem. Eng. J. 2015, 270, 244-271. [CrossRef]

6. Yusuf, M. Agro-industrial waste materials and their recycled value-added applications. Handb. Ecomater. 2017, 1-11. [CrossRef]

7. Oliveira, L.S.; Franca, A.S. Low-cost adsorbents from agri-food wastes. In Food Science and Technology: New Research; Nova Science Publishers: Hauppauge, NY, USA, 2008; Chapter 3; pp. 171-209, ISBN 978-1-60456-715-1.

8. Yadav, S.; Yadav, P.K.; Yadav, D.; Yadav, K.D.S. Purification and characterization of pectin lyase produced by Aspergillus terricola and its application in retting of natural fibers. Appl. Biochem. Biotechnol. 2009, 159, 270-283. [CrossRef] [PubMed]

9. Marinari, S.; Masciandaro, G.; Ceccanti, B.; Grego, S. Influence of organic and mineral fertilisers on soil biological and physical properties. Bioresour. Technol. 2000, 72, 9-17. [CrossRef]

10. Schiewer, S.; Balaria, A. Biosorption of $\mathrm{Pb}^{2+}$ by original and protonated citrus peels: Equilibrium, kinetics, and mechanism. Chem. Eng. J. 2009, 146, 211-219. [CrossRef]

11. Anastopoulos, I.; Margiotoudis, I.; Massas, I. The use of olive tree pruning waste compost to sequestrate methylene blue dye from aqueous solution. Int. J. Phytoremediat. 2018, 20, 831-838. [CrossRef]

12. Landin-Sandoval, V.; Mendoza-Castillo, D.; Bonilla-Petriciolet, A.; Aguayo-Villarreal, I.; Reynel-Avila, H.; Gonzalez-Ponce, H. Valorization of agri-food industry wastes to prepare adsorbents for heavy metal removal from water. J. Environ. Chem. Eng. 2020, 8, 104067. [CrossRef]

13. Maranón, E.; Sastre, H. Ion exchange equilibria of heavy metals onto chemically modified apple residues. Solvent Extr. Ion Exch. 1991, 9, 515-531. [CrossRef]

14. Orlando, U.; Baes, A.; Nishijima, W.; Okada, M. Preparation of agricultural residue anion exchangers and its nitrate maximum adsorption capacity. Chemosphere 2002, 48, 1041-1046. [CrossRef]

15. Orlando, U.; Baes, A.; Nishijima, W.; Okada, M. A new procedure to produce lignocellulosic anion exchangers from agricultural waste materials. Bioresour. Technol. 2002, 83, 195-198. [CrossRef]

16. Marshall, W.E.; Wartelle, L.H. Chromate $\left(\mathrm{CrO}_{4}{ }^{2-}\right)$ and copper $\left(\mathrm{Cu}^{2+}\right)$ adsorption by dual-functional ion exchange resins made from agricultural by-products. Water Res. 2006, 40, 2541-2548. [CrossRef]

17. Wartelle, L.H.; Marshall, W.E. Chromate ion adsorption by agricultural by-products modified with dimethyloldihydroxyethylene urea and choline chloride. Water Res. 2005, 39, 2869-2876. [CrossRef]

18. Wartelle, L.H.; Marshall, W.E. Quaternized agricultural by-products as anion exchange resins. J. Environ. Manag. 2006, 78, 157-162. [CrossRef]

19. Köse, T.E. Agricultural residue anion exchanger for removal of dyestuff from wastewater using full factorial design. Desalination 2008, 222, 323-330. [CrossRef]

20. Johnson, T.A.; Jain, N.; Joshi, H.; Prasad, S. Agricultural and agro-processing wastes as low cost adsorbents for metal removal from wastewater: A review. J. Sci. Ind. Res. 2008, 67, 647-658.

21. Garske, B.; Heyl, K.; Ekardt, F.; Weber, L.M.; Gradzka, W. Challenges of Food Waste Governance An Assessment of European Legislation on Food Waste and Recommendations for Improvement by Economic Instruments. Land 2020, 9, 231. [CrossRef]

22. Papadaki, M.I.; Mendoza-Castillo, D.I.; Reynel-Avila, H.E.; Bonilla-Petriciolet, A.; Georgopoulos, S. Nut Shells as Adsorbents of Pollutants: Research and Perspectives. Front. Chem. Eng. 2021, 3, 19. [CrossRef]

23. Ali, I.; Asim, M.; Khan, T.A. Low cost adsorbents for the removal of organic pollutants from wastewater. J. Environ. Manag. 2012, 113, 170-183. [CrossRef]

24. Crini, G.; Lichtfouse, E.; Wilson, L.; Morin-Crini, N. Green adsorbents for pollutant removal. Environ. Chem. Sustain. World 2018, $18,23-71$.

25. Otero, M.; Rozada, F.; Calvo, L.; Garcia, A.; Moran, A. Elimination of organic water pollutants using adsorbents obtained from sewage sludge. Dye. Pigment. 2003, 57, 55-65. [CrossRef]

26. De Laurentiis, V.; Corrado, S.; Sala, S. Quantifying household waste of fresh fruit and vegetables in the EU. Waste Manag. 2018, 77, 238-251. [CrossRef] [PubMed]

27. Vanham, D.; Bouraoui, F.; Leip, A.; Grizzetti, B.; Bidoglio, G. Lost water and nitrogen resources due to EU consumer food waste. Environ. Res. Lett. 2015, 10, 084008. [CrossRef] 
28. Östergren, K. FUSIONS Definitional Frameword for Food Waste (FP7-Rapport); The Swedish Institute for Food and Biotechnology: Goeteborg, Sweden, 2014; Contract Number: 311972; ISBN 978-91-7290-331-9.

29. Kummu, M.; De Moel, H.; Porkka, M.; Siebert, S.; Varis, O.; Ward, P.J. Lost food, wasted resources: Global food supply chain losses and their impacts on freshwater, cropland, and fertiliser use. Sci. Total. Environ. 2012, 438, 477-489. [CrossRef]

30. Pocketbook, F.S. World Food and Agriculture; FAO: Rome Italy, 2020. [CrossRef]

31. Millati, R.; Cahyono, R.B.; Ariyanto, T.; Azzahrani, I.N.; Putri, R.U.; Taherzadeh, M.J. Agricultural, industrial, municipal, and forest wastes: An Overview. Sustain. Resour. Recovery Zero Waste Approaches 2019, 1-22. [CrossRef]

32. Velmurugan, R.; Muthukumar, K. Utilization of sugarcane bagasse for bioethanol production: Sono-assisted acid hydrolysis approach. Bioresour. Technol. 2011, 102, 7119-7123. [CrossRef] [PubMed]

33. Sewsynker-Sukai, Y.; Kana, E.G. Simultaneous saccharification and bioethanol production from corn cobs: Process optimization and kinetic studies. Bioresour. Technol. 2018, 262, 32-41. [CrossRef]

34. Kim, M.; Kim, B.-C.; Choi, Y.; Nam, K. Minimizing mixing intensity to improve the performance of rice straw anaerobic digestion via enhanced development of microbe-substrate aggregates. Bioresour. Technol. 2017, 245, 590-597. [CrossRef] [PubMed]

35. Guan, R.; Li, X.; Wachemo, A.C.; Yuan, H.; Liu, Y.; Zou, D.; Zuo, X.; Gu, J. Enhancing anaerobic digestion performance and degradation of lignocellulosic components of rice straw by combined biological and chemical pretreatment. Sci. Total Environ. 2018, 637, 9-17. [CrossRef] [PubMed]

36. Michelin, M.; Ruiz, H.A.; Maria de Lourdes, T.; Teixeira, J.A. Multi-step approach to add value to corncob: Production of biomass-degrading enzymes, lignin and fermentable sugars. Bioresour. Technol. 2018, 247, 582-590. [CrossRef] [PubMed]

37. Bhatti, H.; Sadaf, S.; Aleem, A. Treatment of textile effluents by low cost agricultural wastes: Batch biosorption study. J. Anim. Plant Sci. 2015, 25, 284-289.

38. Miura, S.; Arimura, T.; Itoda, N.; Dwiarti, L.; Feng, J.B.; Bin, C.H.; Okabe, M. Production of L-lactic acid from corncob. J. Biosci. Bioeng. 2004, 97, 153-157. [CrossRef]

39. Ragab, T.I.; Amer, H.; Mossa, A.T.; Emam, M.; Hasaballah, A.; Helmy, W.A. Anticoagulation, fibrinolytic and the cytotoxic activities of sulfated hemicellulose extracted from rice straw and husk. Biocatal. Agric. Biotechnol. 2018, 15, 86-91. [CrossRef]

40. Besserer, A.; Troilo, S.; Girods, P.; Rogaume, Y.; Brosse, N. Cascading Recycling of Wood Waste: A Review. Polymers 2021, $13,1752$. [CrossRef]

41. Younas, F.; Mustafa, A.; Farooqi, Z.U.R.; Wang, X.; Younas, S.; Mohy-Ud-Din, W.; Muhammad, A.H.; Muhammad, M.A.; Maitlo, A.A.; Noreen, S.; et al. Current and Emerging Adsorbent Technologies for Wastewater Treatment: Trends, Limitations, and Environmental Implications. Water 2021, 13, 215. [CrossRef]

42. Pyrzynska, K. Removal of cadmium from wastewaters with low-cost adsorbents. J. Environ. Chem. Eng. 2019, 7, 102795. [CrossRef]

43. Nor, N.M.; Lau, L.C.; Lee, K.T.; Mohamed, A.R. Synthesis of activated carbon from lignocellulosic biomass and its applications in air pollution control-a review. J. Environ. Chem. Eng. 2013, 1, 658-666. [CrossRef]

44. Ten, E.; Vermerris, W. Functionalized polymers from lignocellulosic biomass: State of the art. Polymers 2013, 5, 600-642. [CrossRef]

45. TOKUŞOĞLU, Ö. Agri-Food Chain Wastes and Food By-Products: Importance on NutriFood Chemistry and Anticarcinogenity. Food Health Technol. Innov. 2018, 1, 29-33. [CrossRef]

46. Ben-Othman, S.; Jõudu, I.; Bhat, R. Bioactives from agri-food wastes: Present insights and future challenges. Molecules 2020, 25, 510. [CrossRef] [PubMed]

47. FAO. Food Wastage Footprint, Impacts on Natural Resources, Summary Report. 2013. Available online: http://www.fao.org/3/ i3347e/i3347e.pdf (accessed on 13 August 2021).

48. Jenny Gustavsson, C.C.; Sonesson, U.; van Otterdijk, R.; Meybeck, A. Global Food Losses and Food Waste—Extent, Causes and Prevention; Food and Agriculture Organization of the United Nations (FAO): Rome, Italy, 2011.

49. Sagar, N.A.; Pareek, S.; Sharma, S.; Yahia, E.M.; Lobo, M.G. Fruit and vegetable waste: Bioactive compounds, their extraction, and possible utilization. Compr. Rev. Food Sci. Food Saf. 2018, 17, 512-531. [CrossRef] [PubMed]

50. Halada, K.; Yamamoto, R. The current status of research and development on ecomaterials around the world. MRS Bull. 2001, 26, 871-879. [CrossRef]

51. Shahbandeh, M. Global Production of Fruit by Variety Selected 2019. Available online: https://www.statista.com/statistics/2640 01/worldwide-production-of-fruit-by-variety / (accessed on 13 August 2021).

52. Shahbandeh, M. Vegetables: Global Production Volume 2000-2019. Available online: https:/ /www.statista.com/statistics/2640 59/ production-volume-of-vegetables-and-melons-worldwide-since-1990/ (accessed on 13 August 2021).

53. Gustavsson, J.; Cederberg, C.; Sonesson, U.; Van Otterdijk, R.; Meybeck, A. Global food losses and waste: Extent, causes and prevention. In Proceedings of the a Study Conducted for International Congress "Save Food" at Interpack, Dusseldorf, Germany, 12-18 May 2011.

54. Gowe, C. Review on potential use of fruit and vegetables by-products as a valuable source of natural food additives. Food Sci. Qual. Manag. 2015, 45, 47-61.

55. Panouille, M.; Ralet, M.-C.; Bonnin, E.; Thibault, J.-F. Recovery and reuse of trimmings and pulps from fruit and vegetable processing. In Handbook of Waste Management and Co-Product Recovery in Food Processing; Elsevier: Amsterdam, The Netherlands, 2007; pp. 417-447. 
56. Ayala-Zavala, J.; Vega-Vega, V.; Rosas-Domínguez, C.; Palafox-Carlos, H.; Villa-Rodriguez, J.; Siddiqui, M.W.; Dávila-Aviña, J.; González-Aguilar, G. Agro-industrial potential of exotic fruit byproducts as a source of food additives. Food Res. Int. 2011, 44, 1866-1874. [CrossRef]

57. Ravani, A.; Joshi, D. Standardization of processing parameters for the production of Ready-To-Serve unripe Mango beverage (Pana). J. Dairy Foods Home Sci. 2011, 30, 94-98.

58. Schieber, A.; Stintzing, F.C.; Carle, R. By-products of plant food processing as a source of functional compounds-Recent developments. Trends Food Sci. Technol. 2001, 12, 401-413. [CrossRef]

59. Del Borghi, A.; Moreschi, L.; Gallo, M. Circular economy approach to reduce water-energy-food nexus. Curr. Opin. Environ. Sci. Health 2020, 13, 23-28. [CrossRef]

60. Scholz, K. Carbon Footprint of Retail Food Wastage; Independent Thessis: Uppsala, Sweden, 2013.

61. Reay, D. Climate-Smart Bananas. In Climate-Smart Food; Springer International Publishing: New York City, NY, USA, 2019; pp. 81-91.

62. El Barnossi, A.; Moussaid, F; Housseini, A.I. Tangerine, banana and pomegranate peels valorisation for sustainable environment: A review. Biotechnol. Rep. 2020, 29. [CrossRef]

63. Bell, E.M.; Horvath, A. Modeling the carbon footprint of fresh produce: Effects of transportation, localness, and seasonality on US orange markets. Environ. Res. Lett. 2020, 15, 034040. [CrossRef]

64. Litskas, V.D.; Irakleous, T.; Tzortzakis, N.; Stavrinides, M.C. Determining the carbon footprint of indigenous and introduced grape varieties through Life Cycle Assessment using the island of Cyprus as a case study. J. Clean. Prod. 2017, 156, 418-425. [CrossRef]

65. Dwyer, K.; Hosseinian, F.; Rod, M.R. The market potential of grape waste alternatives. J. Food Res. 2014, 3, 91. [CrossRef]

66. Page, G.; Kelly, T.; Minor, M.; Cameron, E. Modeling carbon footprints of organic orchard production systems to address carbon trading: An approach based on life cycle assessment. Hortscience 2011, 46, 324-327. [CrossRef]

67. Galanakis, C.M. Valorization of Fruit Processing By-Products; Academic Press: Chania, Greece, 2019.

68. Carneiro, J.M.; Dias, A.F.; da Silva Barros, V.; Giongo, V.; Matsuura, M.I.d.S.F.; de Figueirêdo, M.C.B. Carbon and water footprints of Brazilian mango produced in the semiarid region. Int. J. Life Cycle Assess. 2019, 24, 735-752. [CrossRef]

69. Durán-Aranguren, D.; Barrera, D.; Carreño, L.; Ríos, J.; Saavedra, D.; Morantes, G.; Sierra, R. Mango Fruit Waste: An Amazing Biorefinery Opportunity. Available online: http:/ / www.etaflorence.it/proceedings/?detail=16339 (accessed on 13 August 2021). [CrossRef]

70. Ntinas, G.K.; Neumair, M.; Tsadilas, C.D.; Meyer, J. Carbon footprint and cumulative energy demand of greenhouse and open-field tomato cultivation systems under Southern and Central European climatic conditions. J. Clean. Prod. 2017, 142, 3617-3626. [CrossRef]

71. Løvdal, T.; Van Droogenbroeck, B.; Eroglu, E.C.; Kaniszewski, S.; Agati, G.; Verheul, M.; Skipnes, D. Valorization of tomato surplus and waste fractions: A case study using Norway, Belgium, Poland, and Turkey as examples. Foods 2019, 8, 229. [CrossRef]

72. Röös, E.; Sundberg, C.; Hansson, P.-A. Uncertainties in the carbon footprint of food products: A case study on table potatoes. Int. J. Life Cycle Assess. 2010, 15, 478-488. [CrossRef]

73. Jagtap, S.; Bhatt, C.; Thik, J.; Rahimifard, S. Monitoring potato waste in food manufacturing using image processing and internet of things approach. Sustainability 2019, 11,3173. [CrossRef]

74. Samotyja, U. Potato Peel as a Sustainable Resource of Natural Antioxidants for the Food Industry. Potato Res. 2019, 62, 435-451. [CrossRef]

75. Healabel. Available online: https://healabel.com/c-ingredients/cabbage (accessed on 7 February 2021).

76. Rogers, G.; Ekman, J.; Titley, M. Identifying New Products, Uses and Markets for Australian Vegetables: A Desktop Study; Horticulture Australia Ltd: Sydney, Australia, 2013; pp. 30-32, ISBN 0734131186.

77. Kreft, C.; Schader, C.; Stolze, M.; Dumondel, M. Lebensmittelverluste in konventionellen und biologischen Gemüsewertschöpfungsketten in der Schweiz am Beispiel von Karotten. In Proceedings of the Grenzen der Qualitätsstrategie im Agrarsektor, Zurich, Switzerland, 1 January 2013; p. 25.

78. Persiani, A.; Diacono, M.; Monteforte, A.; Montemurro, F. Agronomic performance, energy analysis, and carbon balance comparing different fertilization strategies in horticulture under Mediterranean conditions. Environ. Sci. Pollut. Res. 2019, 26, 19250-19260. [CrossRef] [PubMed]

79. FAO. Medium-Term Outlook. In Prospects for Global Production and Trade in Bananas and Tropical Fruits 2019-2028; Food and Agriculture Organization of the United Nations: Rome, Italy, 2020.

80. Ahmad, F.; Zaidi, S. Potential Use of Agro/Food Wastes as Biosorbents in the Removal of Heavy Metals. In Emerging Contaminants; IntechOpen: London, UK, 2020. [CrossRef]

81. Alalwan, H.A.; Kadhom, M.A.; Alminshid, A.H. Removal of heavy metals from wastewater using agricultural byproducts J. Water Supply Res. Technol.AQUA 2020, 69, 99-112. [CrossRef]

82. Achak, M.; Hafidi, A.; Ouazzani, N.; Sayadi, S.; Mandi, L. Low cost biosorbent "banana peel" for the removal of phenolic compounds from olive mill wastewater: Kinetic and equilibrium studies. J. Hazard. Mater. 2009, 166, 117-125. [CrossRef]

83. Bilal, M.; Shah, J.A.; Ashfaq, T.; Gardazi, S.M.H.; Tahir, A.A.; Pervez, A.; Haroon, H.; Mahmood, Q. Waste biomass adsorbents for copper removal from industrial wastewater-A review. J. Hazard. Mater. 2013, 263, 322-333. [CrossRef] [PubMed] 
84. Gupta, V. Application of low-cost adsorbents for dye removal-A review. J. Environ. Manag. 2009, 90, 2313-2342. [CrossRef] [PubMed]

85. Kyzas, G.Z.; Kostoglou, M. Green adsorbents for wastewaters: A critical review. Materials 2014, 7, 333-364. [CrossRef] [PubMed]

86. Li, Y.; Liu, J.; Yuan, Q.; Tang, H.; Yu, F.; Lv, X. A green adsorbent derived from banana peel for highly effective removal of heavy metal ions from water. RSC Adv. 2016, 6, 45041-45048. [CrossRef]

87. Bhatnagar, A.; Sillanpää, M. Utilization of agro-industrial and municipal waste materials as potential adsorbents for water treatment-A review. Chem. Eng. J. 2010, 157, 277-296. [CrossRef]

88. Feng, N.; Guo, X.; Liang, S. Adsorption study of copper (II) by chemically modified orange peel. J. Hazard. Mater. 2009, 164, 1286-1292. [CrossRef]

89. Sha, L.; Xueyi, G.; Ningchuan, F.; Qinghua, T. Adsorption of $\mathrm{Cu}^{2+}$ and $\mathrm{Cd}^{2+}$ from aqueous solution by mercapto-acetic acid modified orange peel. Colloids Surf. B Biointerfaces 2009, 73, 10-14. [CrossRef]

90. Hu, Z.; Srinivasan, M. Mesoporous high-surface-area activated carbon. Microporous Mesoporous Mater. 2001, 43, 267-275. [CrossRef]

91. Lillo-Ródenas, M.; Cazorla-Amorós, D.; Linares-Solano, A. Understanding chemical reactions between carbons and NaOH and $\mathrm{KOH}$ : An insight into the chemical activation mechanism. Carbon 2003, 41, 267-275. [CrossRef]

92. Hayashi, J.i.; Horikawa, T.; Takeda, I.; Muroyama, K.; Ani, F.N. Preparing activated carbon from various nutshells by chemical activation with $\mathrm{K}_{2} \mathrm{CO}_{3}$. Carbon 2002, 40, 2381-2386. [CrossRef]

93. Williams, P.T.; Reed, A.R. Development of activated carbon pore structure via physical and chemical activation of biomass fibre waste. Biomass Bioenergy 2006, 30, 144-152. [CrossRef]

94. Carrott, P.; Carrott, M.R. Lignin-From natural adsorbent to activated carbon: A review. Bioresour. Technol. 2007, 98, $2301-2312$.

95. Yahya, M.A.; Al-Qodah, Z.; Ngah, C.Z. Agricultural bio-waste materials as potential sustainable precursors used for activated carbon production: A review. Renew. Sustain. Energy Rev. 2015, 46, 218-235. [CrossRef]

96. Giraldo, L.; Moreno-Piraján, J.C. Synthesis of activated carbon mesoporous from coffee waste and its application in adsorption zinc and mercury ions from aqueous solution. E-J. Chem. 2012, 9, 938-948. [CrossRef]

97. Tsai, W.-T.; Chang, C.; Lee, S. A low cost adsorbent from agricultural waste corn cob by zinc chloride activation. Bioresour. Technol. 1998, 64, 211-217. [CrossRef]

98. Budinova, T.; Ekinci, E.; Yardim, F.; Grimm, A.; Björnbom, E.; Minkova, V.; Goranova, M. Characterization and application of activated carbon produced by H3PO4 and water vapor activation. Fuel Process. Technol. 2006, 87, 899-905. [CrossRef]

99. Zhu, Z.1.; Li, A.M.; Xia, M.F.; Wan, J.N.; Zhang, Q.X. Preparation and characterization of polymer-based spherical activated carbons. Chin. J. Polym. Sci. 2008, 26, 645-651. [CrossRef]

100. Lozano-Castello, D.; Lillo-Ródenas, M.; Cazorla-Amorós, D.; Linares-Solano, A. Preparation of activated carbons from Spanish anthracite: I. Activation by KOH. Carbon 2001, 39, 741-749. [CrossRef]

101. Barakat, M. New trends in removing heavy metals from industrial wastewater. Arab. J. Chem. 2011, 4, 361-377. [CrossRef]

102. Akpor, O.; Otohinoyi, D.; Olaolu, D.; Aderiye, B. Pollutants in wastewater effluents: Impacts and remediation processes. Int. J. Environ. Res. Earth Sci. 2014, 3, 050-059.

103. Harvey, P.; Handley, H.; Taylor, M. Identification of the sources of metal (lead) contamination in drinking waters in north-eastern Tasmania using lead isotopic compositions. Environ. Sci. Pollut. Res. 2015, 22, 12276-12288. [CrossRef] [PubMed]

104. Ali, M. Assessment of some water quality characteristics and determination of some heavy metals in Lake Manzala, Egypt. Egypt. J. Aquat. Biol. Fish. 2008, 12, 133-154. [CrossRef]

105. Rashed, M.N. Adsorption technique for the removal of organic pollutants from water and wastewater. Org. Pollut-Monit. Risk Treat. 2013, 7, 167-194. [CrossRef]

106. Fu, F.; Wang, Q. Removal of heavy metal ions from wastewaters: A review. J. Environ. Manag. 2011, 92, 407-418. [CrossRef]

107. Yadav, M.; Gupta, R.; Arora, G.; Yadav, P.; Srivastava, A.; Sharma, R.K. Current Status of Heavy Metal Contaminants and Their Removal/Recovery Techniques. In Contaminants in Our Water: Identification and Remediation Methods; ACS Publications: Washington, DC, USA, 2020; pp. 41-64.

108. Bolisetty, S.; Peydayesh, M.; Mezzenga, R. Sustainable technologies for water purification from heavy metals: Review and analysis. Chem. Soc. Rev. 2019, 48, 463-487. [CrossRef] [PubMed]

109. Guechi, E.-K.; Hamdaoui, O. Evaluation of potato peel as a novel adsorbent for the removal of Cu (II) from aqueous solutions: Equilibrium, kinetic, and thermodynamic studies. Desalination Water Treat. 2016, 57, 10677-10688. [CrossRef]

110. El-Azazy, M.; El-Shafie, A.S.; Issa, A.A.; Al-Sulaiti, M.; Al-Yafie, J.; Shomar, B.; Al-Saad, K. Potato peels as an adsorbent for heavy metals from aqueous solutions: Eco-structuring of a green adsorbent operating Plackett-Burman design. J. Chem. 2019, 2019. [CrossRef]

111. Feizi, M.; Jalali, M. Removal of heavy metals from aqueous solutions using sunflower, potato, canola and walnut shell residues. J. Taiwan Inst. Chem. Eng. 2015, 54, 125-136. [CrossRef]

112. Moreno-Piraján, J.; Giraldo, L. Activated carbon obtained by pyrolysis of potato peel for the removal of heavy metal copper (II) from aqueous solutions. J. Anal. Appl. Pyrolysis 2011, 90, 42-47. [CrossRef]

113. Kyzas, G.Z.; Deliyanni, E.A.; Matis, K.A. Activated carbons produced by pyrolysis of waste potato peels: Cobalt ions removal by adsorption. Colloids Surf. A Physicochem. Eng. Asp. 2016, 490, 74-83. [CrossRef] 
114. Kyzas, G.Z.; Bomis, G.; Kosheleva, R.I.; Efthimiadou, E.K.; Favvas, E.P.; Kostoglou, M.; Mitropoulos, A.C. Nanobubbles effect on heavy metal ions adsorption by activated carbon. Chem. Eng. J. 2019, 356, 91-97. [CrossRef]

115. Aman, T.; Kazi, A.A.; Sabri, M.U.; Bano, Q. Potato peels as solid waste for the removal of heavy metal copper (II) from waste water/industrial effluent. Colloids Surf. B: Biointerfaces 2008, 63, 116-121. [CrossRef]

116. Gutha, Y.; Munagapati, V.S.; Naushad, M.; Abburi, K. Removal of Ni (II) from aqueous solution by Lycopersicum esculentum (Tomato) leaf powder as a low-cost biosorbent. Desalination Water Treat. 2015, 54, 200-208. [CrossRef]

117. Heraldy, E.; Lestari, W.W.; Permatasari, D.; Arimurti, D.D. Biosorbent from tomato waste and apple juice residue for lead removal. J. Environ. Chem. Eng. 2018, 6, 1201-1208. [CrossRef]

118. Hossain, M.; Ngo, H.; Guo, W.; Nguyen, T.; Vigneswaran, S. Performance of cabbage and cauliflower wastes for heavy metals removal. Desalination Water Treat. 2014, 52, 844-860. [CrossRef]

119. Nasernejad, B.; Zadeh, T.E.; Pour, B.B.; Bygi, M.E.; Zamani, A. Camparison for biosorption modeling of heavy metals (Cr (III), Cu (II), Zn (II)) adsorption from wastewater by carrot residues. Process. Biochem. 2005, 40, 1319-1322. [CrossRef]

120. Qin, T.; Wang, Z.; Xie, X.; Xie, C.; Zhu, J.; Li, Y. A novel biochar derived from cauliflower (Brassica oleracea L.) roots could remove norfloxacin and chlortetracycline efficiently. Water Sci. Technol. 2017, 76, 3307-3318. [CrossRef]

121. Potato News Today. Available online: https://www.potatonewstoday.com/2020/02/25/world-potato-congress-report-revisedfao-figures-show-slowdown-in-the-rise-of-global-potato-production/ (accessed on 16 December 2020).

122. Sepelev, I.; Galoburda, R. Industrial potato peel waste application in food production: A review. Res Rural. Dev 2015, 1, 130-136.

123. Sogi, D.; Bhatia, R.; Garg, S.; Bawa, A. Biological evaluation of tomato waste seed meals and protein concentrate. Food Chem. 2005, 89, 53-56. [CrossRef]

124. Programme, U.N.E. Food Waste Index Report 2021; United Nations Environment Programme: Nairobi, Kenya, 2021.

125. Westphal, A.; Bauerfeind, J.; Rohrer, C.; Böhm, V. Analytical characterisation of the seeds of two tomato varieties as a basis for recycling of waste materials in the food industry. Eur. Food Res. Technol. 2014, 239, 613-620. [CrossRef]

126. Liang, J.L. Functional Properties of Wastes from Cabbage (Brassica Oleracea L. Var. Capitata) and Capsicum (Capsicum Annuum L. Var. Annum); UTAR: Perak, Malaysia, 2016.

127. Khedkar, M.A.; Nimbalkar, P.R.; Chavan, P.V.; Chendake, Y.J.; Bankar, S.B. Cauliflower waste utilization for sustainable biobutanol production: Revelation of drying kinetics and bioprocess development. Bioprocess Biosyst. Eng. 2017, 40, 1493-1506. [CrossRef] [PubMed]

128. Kaur, G.J.; Kumar, D.; Orsat, V.; Singh, A. Assessment of carrot rejects and wastes for food product development and as a biofuel. Biomass Convers. Biorefin. 2020, 1-12. [CrossRef]

129. Ajmal, M.; Rao, R.A.K.; Ahmad, R.; Ahmad, J. Adsorption studies on Citrus reticulata (fruit peel of orange): Removal and recovery of $\mathrm{Ni}$ (II) from electroplating wastewater. J. Hazard. Mater. 2000, 79, 117-131. [CrossRef]

130. Li, X.; Tang, Y.; Cao, X.; Lu, D.; Luo, F.; Shao, W. Preparation and evaluation of orange peel cellulose adsorbents for effective removal of cadmium, zinc, cobalt and nickel. Colloids Surf. A Physicochem. Eng. Asp. 2008, 317, 512-521. [CrossRef]

131. Schiewer, S.; Patil, S.B. Pectin-rich fruit wastes as biosorbents for heavy metal removal: Equilibrium and kinetics. Bioresour. Technol. 2008, 99, 1896-1903. [CrossRef] [PubMed]

132. Annadurai, G.; Juang, R.-S.; Lee, D. Adsorption of heavy metals from water using banana and orange peels. Water Sci. Technol. 2003, 47, 185-190. [CrossRef]

133. Razafsha, A.; Ziarati, P. Removal of heavy metals from Oryza sativa rice by sour lemon peel as bio-sorbent. Biomed. Pharmacol. J. 2016, 9, 543-553. [CrossRef]

134. Dhakal, R.P.; Ghimire, K.N.; Inoue, K. Adsorptive separation of heavy metals from an aquatic environment using orange waste. Hydrometallurgy 2005, 79, 182-190. [CrossRef]

135. Li, X.; Tang, Y.; Xuan, Z.; Liu, Y.; Luo, F. Study on the preparation of orange peel cellulose adsorbents and biosorption of Cd ${ }^{2+}$ from aqueous solution. Sep. Purif. Technol. 2007, 55, 69-75. [CrossRef]

136. Namasivayam, C.; Muniasamy, N.; Gayatri, K.; Rani, M.; Ranganathan, K. Removal of dyes from aqueous solutions by cellulosic waste orange peel. Bioresour. Technol. 1996, 57, 37-43. [CrossRef]

137. Fernandez, M.E.; Nunell, G.V.; Bonelli, P.R.; Cukierman, A.L. Activated carbon developed from orange peels: Batch and dynamic competitive adsorption of basic dyes. Ind. Crop. Prod. 2014, 62, 437-445. [CrossRef]

138. Chen, J.Q.; Hu, Z.J.; Ji, R. Removal of carbofuran from aqueous solution by orange peel. Desalination Water Treat. 2012, 49, 106-114. [CrossRef]

139. Xu, G.F.; Jing, H.M.; Guo, R.X. The adsorption isotherm studies of orange peel on pesticide furadan. In Proceedings of the Applied Mechanics and Materials, 2014; International Conference on Mechanics and Mechanical Engineering, Wuhan, China, 13-14 September 2014; pp. 1331-1335.

140. Guo, X.Y.; Liang, S.; Tian, Q.H. Removal of heavy metal ions from aqueous solutions by adsorption using modified orange peel as adsorbent. Available online: https:/ / www.scientific.net/AMR.236-238.237 (accessed on 13 August 2021).

141. Nakajima, A.; Sakaguchi, T. Recovery and removal of uranium by using plant wastes. Biomass 1990, 21, 55-63. [CrossRef]

142. Tasaso, P. Adsorption of copper using pomelo peel and depectinated pomelo peel. J. Clean Energy Technol. 2014, 2, 154-157. [CrossRef]

143. Liu, J.; Huang, G.; Deng, J.; Liu, K.; Xie, Y. Adsorbent prepared from waste pomelo peel and its adsorption of $\mathrm{Pb}^{2+}$ in wastewater. J. Ecol. Rural. Environ. 2012, 28, 187-191. 
144. Hou, S.X. Adsorption Properties of Pomelo Peels against Methylene Blue in Dye Wastewater. In Proceedings of the Advanced Materials Research. Available online: https:/ /www.scientific.net/AMR.634-638.178 (accessed on 13 August 2021).

145. Bello, O.S.; Ahmad, M.A.; Semire, B. Scavenging malachite green dye from aqueous solutions using pomelo (Citrus grandis) peels: Kinetic, equilibrium and thermodynamic studies. Desalination Water Treat. 2015, 56, 521-535. [CrossRef]

146. Saeed, A.; Sharif, M.; Iqbal, M. Application potential of grapefruit peel as dye sorbent: Kinetics, equilibrium and mechanism of crystal violet adsorption. J. Hazard. Mater. 2010, 179, 564-572. [CrossRef]

147. Zou, W.; Zhao, L.; Zhu, L. Efficient uranium (VI) biosorption on grapefruit peel: Kinetic study and thermodynamic parameters. J. Radioanal. Nucl. Chem. 2012, 292, 1303-1315. [CrossRef]

148. Bhatnagar, A.; Kumar, E.; Minocha, A.; Jeon, B.-H.; Song, H.; Seo, Y.-C. Removal of anionic dyes from water using Citrus limonum (lemon) peel: Equilibrium studies and kinetic modeling. Sep. Sci. Technol. 2009, 44, 316-334. [CrossRef]

149. Tembhurkar, A.; Deshpande, R.P. Powdered Activated Lemon Peels as Adsorbent for Removal of Cutting Oil from Wastewater. J. Hazard. Toxic Radioact. Waste 2012, 16, 311-315. [CrossRef]

150. Panadare, D.C.; Lade, V.G.; Rathod, V.K. Adsorptive removal of copper (II) from aqueous solution onto the waste sweet lime peels (SLP): Equilibrium, kinetics and thermodynamics studies. Desalination Water Treat. 2014, 52, 7822-7837. [CrossRef]

151. Anwar, J.; Shafique, U.; Salman, M.; Dar, A.; Anwar, S. Removal of Pb (II) and Cd (II) from water by adsorption on peels of banana. Bioresour. Technol. 2010, 101, 1752-1755. [CrossRef] [PubMed]

152. Amela, K.; Hassen, M.A.; Kerroum, D. Isotherm and kinetics study of biosorption of cationic dye onto banana peel. Energy Procedia 2012, 19, 286-295. [CrossRef]

153. Silva, C.R.; Gomes, T.F.; Andrade, G.C.; Monteiro, S.H.; Dias, A.C.; Zagatto, E.A.; Tornisielo, V.L. Banana peel as an adsorbent for removing atrazine and ametryne from waters. J. Agric. Food Chem. 2013, 61, 2358-2363. [CrossRef] [PubMed]

154. Chaparadza, A.; Hossenlopp, J.M. Adsorption kinetics, isotherms and thermodynamics of atrazine removal using a banana peel based sorbent. Water Sci. Technol. 2012, 65, 940-947. [CrossRef]

155. Mohammed, R.R.; Chong, M.F. Treatment and decolorization of biologically treated Palm Oil Mill Effluent (POME) using banana peel as novel biosorbent. J. Environ. Manag. 2014, 132, 237-249. [CrossRef] [PubMed]

156. Abdulfatai, J.; Saka, A.A.; Afolabi, A.S.; Micheal, O. Development of adsorbent from banana peel for wastewater treatment. In Proceedings of the Applied Mechanics and Materials, International Conference on Mechanics and Mechanical Engineering, Wuhan, China, 13-14 September 2013; pp. 310-315.

157. Mallampati, R.; Valiyaveettil, S. Apple Peels A Versatile Biomass for Water Purification? ACS Appl. Mater. Interfaces 2013, 5, 4443-4449. [CrossRef]

158. Iqbal, M.; Saeed, A.; Kalim, I. Characterization of adsorptive capacity and investigation of mechanism of $\mathrm{Cu}^{2+}, \mathrm{Ni}^{2+}$ and $\mathrm{Zn}^{2+}$ adsorption on mango peel waste from constituted metal solution and genuine electroplating effluent. Sep. Sci. Technol. 2009, 44, 3770-3791. [CrossRef]

159. USDA. Citrus: World Markets and Trade. Global Market Analysis; United States Department of Agriculture-Foreign Agricultural Service: Washington, DC, USA, 2021.

160. FAO. BANANA Market Review 2019; Food and Agriculture Organization of the United Nations: Rome, Italy, 2020.

161. Rana, G.K.; Singh, Y.; Mishra, S.; Rahangdale, H.K. Potential use of banana and its by-products: A review. Int. J. Curr. Microbiol. App. Sci. 2018, 7, 1827-1832. [CrossRef]

162. Shahbandeh, M. Apple Production Worldwide 2010-2019. Available online: https://www.statista.com/statistics/961248 / production-of-apples-worldwide/ (accessed on 13 August 2021).

163. Dhillon, G.S.; Kaur, S.; Brar, S.K. Perspective of apple processing wastes as low-cost substrates for bioproduction of high value products: A review. Renew. Sustain. Energy Rev. 2013, 27, 789-805. [CrossRef]

164. Khan, N.; Fahad, S.; Naushad, M.; Faisal, S. Grape Production Critical Review in the World. SSRN 2020, SSRN:3595842. [CrossRef]

165. Ioannou, L.; Puma, G.L.; Fatta-Kassinos, D. Treatment of winery wastewater by physicochemical, biological and advanced processes: A review. J. Hazard. Mater. 2015, 286, 343-368. [CrossRef] [PubMed]

166. Chouchouli, V.; Kalogeropoulos, N.; Konteles, S.J.; Karvela, E.; Makris, D.P.; Karathanos, V.T. Fortification of yoghurts with grape (Vitis vinifera) seed extracts. LWT-Food Sci. Technol. 2013, 53, 522-529. [CrossRef]

167. Shahbandeh, M. Global Mango Production 2000-2019. Available online: https://www.statista.com/statistics/577951/worldmango-production/ (accessed on 13 August 2021).

168. Ramasamy, M.; Srirangarayan, R.S.; Shanmugasundaram, R.; Ramesh, P.; Shrirangasami, S.; Prasanthrajan, M.; Saravanakumar, S. Composting of Mango Wastes. Biot. Res. Today 2020, 2, 1034-1035.

169. Sakaguchi, T.; Nakajima, A. Recovery of uranium from seawater by immobilized tannin. Sep. Sci. Technol. 1987, 22, 1609-1623. [CrossRef]

170. Azargohar, R.; Dalai, A. Biochar as a precursor of activated carbon. In Proceedings of the Twenty-Seventh Symposium on Biotechnology for Fuels and Chemicals, Twenty-Seventh Symposium on Biotechnology for Fuels and Chemicals, Denver, CO, USA, 1-4 May 2005; pp. 762-773.

171. Bello, O.S.; Ahmad, M.A.; Ahmad, N. Adsorptive features of banana (Musa paradisiaca) stalk-based activated carbon for malachite green dye removal. Chem. Ecol. 2012, 28, 153-167. [CrossRef]

172. Dias, J.M.; Alvim-Ferraz, M.C.; Almeida, M.F.; Rivera-Utrilla, J.; Sánchez-Polo, M. Waste materials for activated carbon preparation and its use in aqueous-phase treatment: A review. J. Environ. Manag. 2007, 85, 833-846. [CrossRef] 
173. Getachew, T.; Hussen, A.; Rao, V. Defluoridation of water by activated carbon prepared from banana (Musa paradisiaca) peel and coffee (Coffea arabica) husk. Int. J. Environ. Sci. Technol. 2015, 12, 1857-1866. [CrossRef]

174. Ioannidou, O.; Zabaniotou, A. Agricultural residues as precursors for activated carbon production-A review. Renew. Sustain. Energy Rev. 2007, 11, 1966-2005. [CrossRef]

175. Mohammad, S.G.; Ahmed, S.M.; Badawi, A.F.M.; El-Desouki, D. Activated carbon derived from egyptian banana peels for removal of cadmium from water. J. Appl. Life Sci. Int. 2015, 3, 77-88. [CrossRef]

176. Salman, J.; Hameed, B. Removal of insecticide carbofuran from aqueous solutions by banana stalks activated carbon. J. Hazard. Mater. 2010, 176, 814-819. [CrossRef] [PubMed]

177. De Gisi, S.; Lofrano, G.; Grassi, M.; Notarnicola, M. Characteristics and adsorption capacities of low-cost sorbents for wastewater treatment: A review. Sustain. Mater. Technol. 2016, 9, 10-40. [CrossRef]

178. Sulyman, M.; Namiesnik, J.; Gierak, A. Low-cost Adsorbents Derived from Agricultural By-products/Wastes for Enhancing Contaminant Uptakes from Wastewater: A Review. Pol. J. Environ. Stud. 2017, 26, 479-510. [CrossRef]

179. Kurniawan, T.A.; Chan, G.Y.; Lo, W.-h.; Babel, S. Comparisons of low-cost adsorbents for treating wastewaters laden with heavy metals. Sci. Total Environ. 2006, 366, 409-426. [CrossRef]

180. Bharathi, K.; Ramesh, S. Removal of dyes using agricultural waste as low-cost adsorbents: A review. Appl. Water Sci. 2013, 3, 773-790. [CrossRef] 